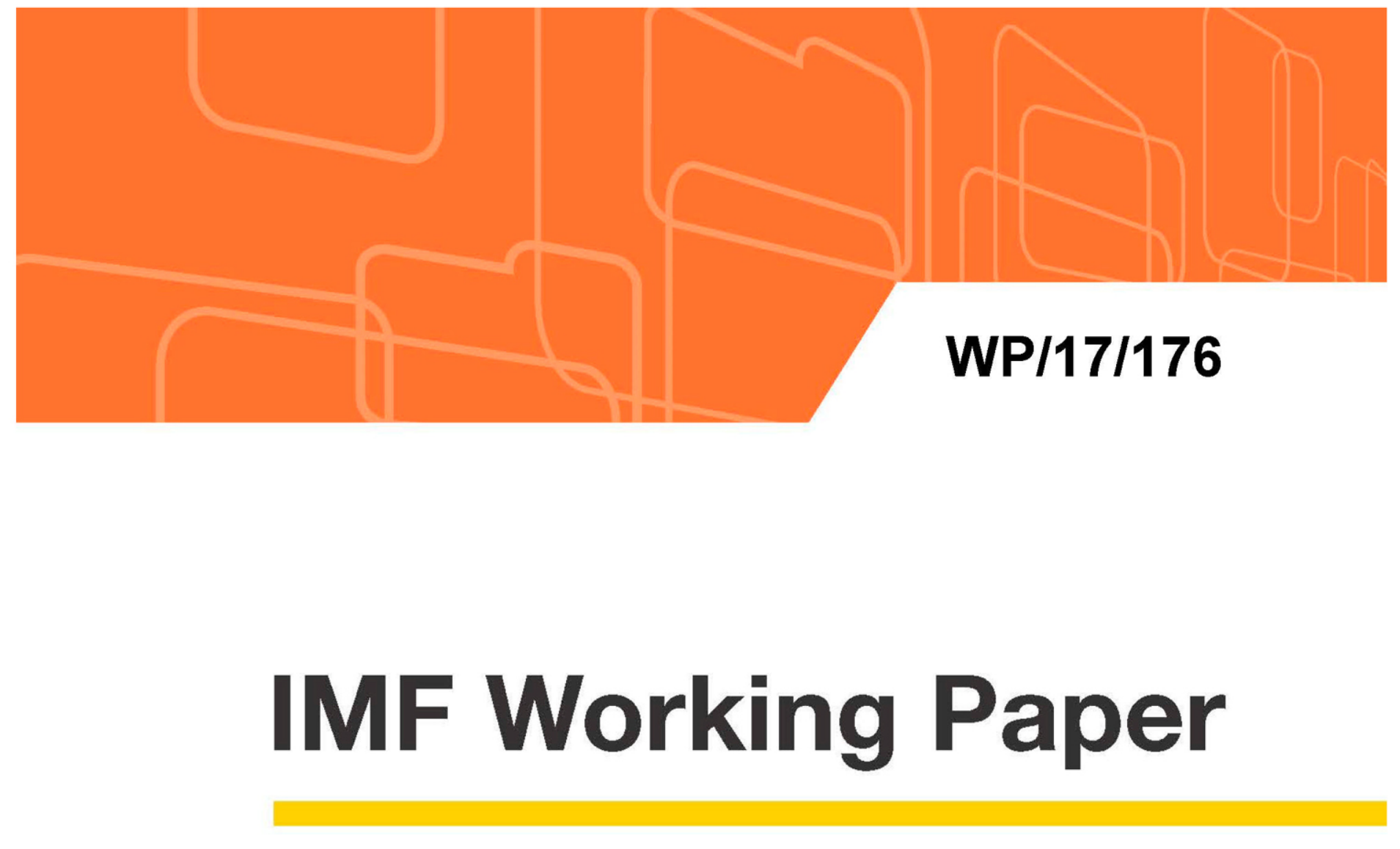

\title{
The Financing of Ideas and the Great Deviation
}

\author{
by Daniel Garcia-Macia
}

IMF Working Papers describe research in progress by the author(s) and are published to elicit comments and to encourage debate. The views expressed in IMF Working Papers are those of the author(s) and do not necessarily represent the views of the IMF, its Executive Board, or IMF management. 


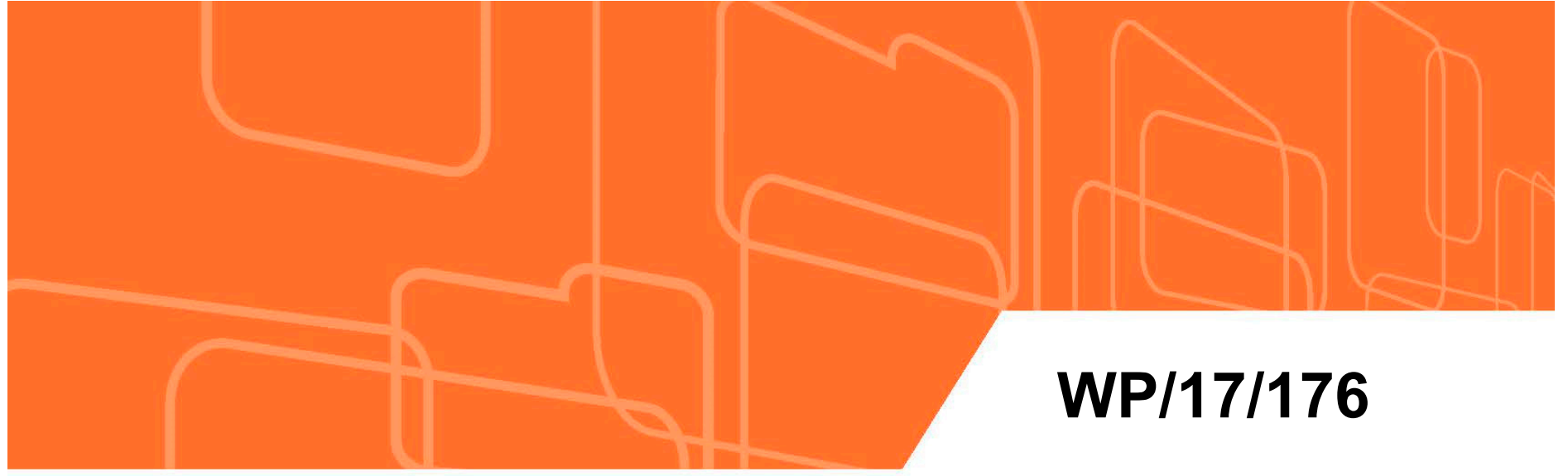

\section{IMF Working Paper}

\section{The Financing of Ideas and the Great Deviation}

by Daniel Garcia-Macia

IMF Working Papers describe research in progress by the author(s) and are published to elicit comments and to encourage debate. The views expressed in IMF Working Papers are those of the author(s) and do not necessarily represent the views of the IMF, its Executive Board, or IMF management. 


\title{
IMF Working Paper
}

\author{
Research Department
}

The Financing of Ideas and the Great Deviation ${ }^{1}$

Prepared by Daniel Garcia-Macia

Authorized for distribution by Luis Cubeddu

July 2017

IMF Working Papers describe research in progress by the author(s) and are published to elicit comments and to encourage debate. The views expressed in IMF Working Papers are those of the author(s) and do not necessarily represent the views of the IMF, its Executive Board, or IMF management.

\begin{abstract}
Why did the Great Recession lead to such a slow recovery? I build a model where heterogeneous firms invest in physical and intangible capital, and can default on their debt. In case of default, intangible assets are harder to seize by creditors. Hence, intangible capital faces higher financing costs. This differential is exacerbated in a financial crisis, when default is more likely and aggregate risk bears a higher premium. The resulting fall in intangible investment amplifies the crisis, and gradual intangible spillovers to other firms contribute to its persistence. Using panel data on Spanish manufacturing firms, I estimate the model matching firm-level moments regarding intangibles and financing. The model captures the extent and components of the Great Recession in Spanish manufacturing, whereas a standard model without endogenous intangible investment would miss more than half of the GDP fall. A policy of transfers conditional on firm age could speed up the recovery, as young firms tend to be more financially constrained, particularly regarding intangible investment. Conditioning transfers on firm size or subsidizing credit (as in current E.U. policy) appears to be less effective.

JEL Classification Numbers: E22, G01, G32.

Keywords: financial crises, intangible capital, heterogeneous firms, endogenous default. Author's E-Mail Address: DGarciaMacia@imf.org

\footnotetext{
${ }^{1}$ I am grateful to my thesis advisors Peter J. Klenow, Martin Schneider, Nick Bloom and Monika Piazzesi for their invaluable guidance on this project. I also benefited from the comments of Frederic Boissay, Diego Comin, Andres Drenik, Jordi Gali, Arvind Krishnamurthy, Pablo Kurlat, Robert E. Hall, Charles I. Jones, Serguei Maliar, Alonso Villacorta, and several seminar participants. This research was supported by the Ewing Marion Kauffman Foundation and by the Shultz Graduate Student Fellowship in Economic Policy through a grant to the Stanford Institute for Economic Policy and Research. The views expressed herein are those of the author and should not be attributed to the Kauffman Foundation.
} 


\section{Introduction}

The 2007-2008 Global Financial Crisis has been followed by a large contraction in GDP and a particularly slow recovery in many developed economies, especially in the European periphery. Figure 1 illustrates these facts for Spain, comparing the deviation of real GDP per capita from trend after the peak in recent financial and non-financial recessions. I classify a recession as financial if it is accompanied by an atypical increase in the equity premium in financial markets. Figure 1 shows that the Great Recession has turned into a "Great Deviation" of output from trend.

Figure 1: Real GDP per Capita after Recent Recessions, Spain

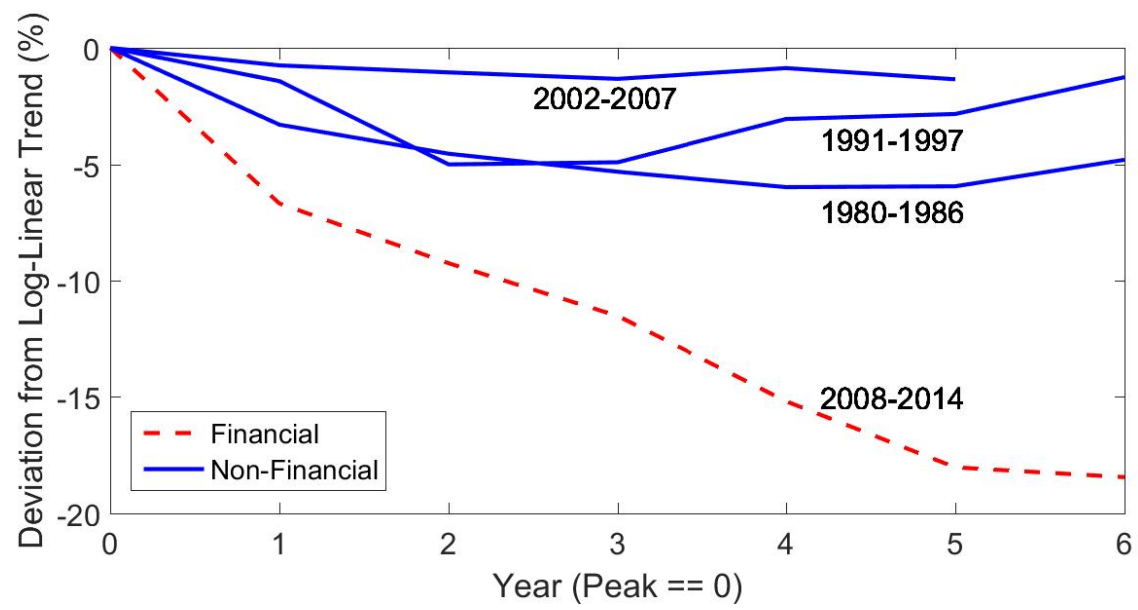

This paper presents a model that explains why the response of the real economy can be larger and more persistent after a financial shock than after other types of shocks. The mechanism is based on the interaction between investment in intangible capital and financial constraints. Financial shocks make financing intangibles disproportionately more costly, and the consequent fall in intangible (and tangible) capital accumulation generates a prolonged deviation in output. I estimate the model with panel data on Spanish manufacturing firms and find that modeling intangible investment accounts for more than half of the fall in value added between 2008 and 2013. The paper also delivers quantitative recommendations for fiscal policy based on firm characteristics.

I model the corporate sector in a small open economy. Heterogeneous firms invest in physical (or tangible) capital and in intangible capital. Intangible investment includes all expenditures in non-physical assets aimed at increasing the productivity of a firm. Thus, it captures the formation and adoption of both technological and organizational capital. Firms finance their investments with internal equity and debt - the most common channels in Europe. Yet, they have limited commitment and can default on their debt obligations. The corporate sector is subject to financial and non-financial aggregate shocks. Both types 
of shocks feature a fall in foreign income, which reduces the demand for domestic firms. But financial shocks also feature an increase in the price of aggregate risk in global financial markets, which makes financing risky firm debt more expensive. This is consistent with the evidence that the risk premium rises in financial crises, whereas the risk-free rate is barely affected. As in previous macroeconomic models, financial frictions amplify both types of aggregate shocks. However, the novel result in my model is that shocks which are financial in nature lead to additional amplification and persistence.

The amplification mechanism is related to the financial properties of intangible capital. I estimate that intangible assets are harder to pledge as collateral than tangible assets. Therefore, in case of default, creditors expect lower recovery rates for intangible-capital intensive firms. Moreover, all firms are more likely to default in bad states of the world. Given these two equilibrium results, the debt of intangible-capital-intensive firms carries more aggregate risk, i.e., its repayment rates covary more with the aggregate state. Hence, financing investment in intangible capital always tends to be more costly than financing tangible investments. Yet, this differential widens when a financial shock hits the economy, as creditors discount aggregate risk more heavily. Since cutting intangible investment is subject to convex adjustment costs, both tangible and intangible investment are curtailed after a financial shock. The rise in financing costs also causes an increase in firm default and exit rates, especially for intangible-intensive firms, which entails efficiency losses. Thus, both the intensive and extensive margins propagate the GDP decline.

Indeed, the Spanish firm-level data confirms that the Great Recession came together with a particularly large fall in the debt issuances and investment rates of intangible-capitalintensive firms and industries, a considerable deterioration in several intangible investment and productivity measures, and a surge in firm exit rates. None of these facts can be replicated by a standard model without endogenous intangible investment.

The properties of intangible capital also lead to two channels of persistence. First, I estimate that investment adjustment costs are higher for intangible capital. This implies that entrants replacing exited firms take more time to reach the mature level of intangible capital than that of tangible capital. Second, my model allows for gradual spillovers of intangible capital to other firms in the economy. Such spillovers can take the form of diffusion of knowledge about technological and organizational processes, new products, or domestic and foreign market conditions. Individual firms perceive spillovers of their own intangible capital to other firms as private depreciation, but public intangible capital, which accumulates with spillovers, does not depreciate. It is therefore a slow-moving variable that contributes to generate low-frequency fluctuations. As a result, any shock that affects intangibles disproportionately more, such as a financial shock, also causes more persistence.

CInternational Monetary Fund. Not for Redistribution 
The quantitative part of this paper estimates the model using a high-quality representative panel of Spanish manufacturing firms from 1990 to 2013, the Survey on Business Strategies. This dataset is unique in that it features very detailed information on firms' tangible and intangible investment expenditures, together with complete balance-sheet information on assets and liabilities, including the stock of tangible and intangible assets. Intangible investment is disaggregated into R\&D, marketing and advertising, technology imports and training of workers, with the first two categories accounting for the largest share. The dataset covers small and medium enterprises, which represent a large share of the market in Europe, and an even larger share of investment and job creation. I complement this sample with information on the entire manufacturing firm population from the Public Registry of Firms.

The model parameters are estimated by indirect inference, matching key firm-level moments regarding cross-sectional and within-firm patterns of investment and financing. In the model, firm heterogeneity is due to the presence of firm-idiosyncratic persistent shocks to the private depreciation of intangible capital. Targeted moments include tangible and intangible investment rates as a function of firm characteristics and their within-firm volatility, average leverage across firms, firm life-cycle growth, and aggregate entry and exit rates. I infer that intangible assets are less collateralizable from the empirical observation that intangible investment is more negatively related to firm leverage. I also estimate that intangible capital has higher adjustment costs, as the within-firm volatility of intangible investment rates is lower, and that it has a higher private depreciation rate, as intangible investment rates remain high for mature firms. The private depreciation rate of intangible capital disciplines the intensity of the spillover channel. Importantly, the model targets average firm leverage. Considering the endogenous response of intangible investment allows for large and persistent effects of financial shocks without assuming unrealistically high levels for firm's external-financing dependence.

Next, I compare model-simulated aggregate data against the evolution of the macro time series in the Spanish manufacturing sector. The model takes the observed dynamics of aggregate prices as given. State prices in financial markets and foreign income shocks are directly estimated with data on the expected equity premium and GDP in the rest of the European Union. Therefore, the comparison with the Spanish macro data serves as an overidentifying check of the model. The simulated model can fit both the extent and the components of the Great Deviation that followed the Great Recession. Specifically, the new channels described in this paper: lower intangible investment rates and higher firm exit rates, are key drivers of amplification, together with the fall in employment due to the rigid behavior of wages. In contrast, a standard model of heterogeneous firms and collateral constraints, but no endogenous intangible investment, would miss two thirds of the observed 
GDP fall from 2008 to 2013. The main structural cause of this gap between models is the lack of collateralizability of intangibles, while the presence of spillovers is a lesser factor.

The need to speed up the recovery is at the center of the policy debate in Europe. With this goal in mind, the European Commission has implemented a policy of subsidized credit to risky investments, the so-called Juncker Plan. This paper proposes an alternative policy that could be more effective in increasing aggregate investment at no public cost: a budgetneutral scheme of transfers based on firm age. Such a policy mitigates the consequences of a financial shock because it relaxes the borrowing constraints of younger firms, which tend to have higher returns to investment in tangible and especially intangible capital, moving the economy closer to the first-best allocation. If implemented unanticipatedly in 2009, this policy could have avoided 17 percent of the 2008-2013 GDP fall, according to the model. Conditioning transfers on firm size is less efficient than conditioning on age, as an important fraction of small firms are not financially constrained. In a framework with endogenous borrowing constraints, subsidized credit fails to increase the debt capacity of a firm and crowds out private credit. Thus, the current E.U. policy seems to be dominated by welltargeted outright transfers, which in practice could be implemented via corporate income or social security tax credits.

The rest of the paper is organized as follows. Section 2 highlights the main contributions to the literature. Section 3 covers the model and the theoretical mechanism. Section 4 describes the aggregate and firm-level data. The estimation strategy and results are presented in Section 5. Section 6 contains the quantitative macroeconomic results and the policy analysis. Section 7 concludes.

\section{Related Literature}

This paper is motivated by the empirical literature on the macroeconomic consequences of financial crises. Muir (2017) shows that periods of financial turmoil are associated with increases in spreads in financial markets, and these increases tend to predict persistent declines in output (Gilchrist and Zakrajšek (2012) and Krishnamurthy and Muir (2016)) and TFP (Redmond and Van Zandweghe (2016)). Reinhart and Rogoff (2009) document the persistence of financial recessions (defined as banking crises) across countries and over time, while Jorda et al. (2013) show that financial recessions tend to last longer than nonfinancial recessions, even conditioning on the magnitude of the fall in output.

Starting with Bernanke and Gertler (1989), there is an ample body of research modeling the impact of financial frictions on the economic cycle. Quantitative papers in this literature

include Bernanke et al. (1999), Mendoza (2010), Gertler and Karadi (2011), Gertler and 
Kiyotaki (2013). A series of papers also consider the effects of financial shocks on aggregate productivity due to misallocation across heterogeneous firms. Gomes and Schmid (2010), Buera et al. (2011), Gilchrist et al. (2013), Khan and Thomas (2013), Khan et al. (2014), Midrigan and $\mathrm{Xu}$ (2014), Buera and Moll (2015) and Gopinath et al. (2017) are among recent contributions. However, these papers do not study the endogenous decision of a firm to invest in its productivity. The effects on aggregate productivity they obtain are caused by compositional changes after exogenous shocks.

Another branch of the literature, stemming from the work of King and Levine (1993) and Rajan and Zingales (1998), has focused on the link between financing and innovation (which is a form of intangible investment). Aghion et al. (2010) develop a model with two-period firms where the fact that investment in innovation has a longer time horizon can explain why financial recessions are more persistent. Allowing for a lower private depreciation rate of intangibles would amplify the persistence of crises in my model. Yet, both Corrado et al. (2012) and my own estimates show significantly higher depreciation rates for all categories of intangible capital, including R\&D, than for physical capital. Thus, I focus on the financial properties of intangibles, as well as on the spillovers of intangible capital to other firms, which decouple (high) private depreciation rates from (low) social depreciation rates.

Guerrón-Quintana and Jinnai (2015) and Queraltó (2016) build upon the medium-run business cycle model of Comin and Gertler (2006), which adds business cycle fluctuations to an endogenous growth model, to calibrate the aggregate role of endogenous innovation after recent financial recessions. In a similar framework with New-Keynesian elements, Bianchi and Kung (2014), Benigno and Fornaro (2015), Garga and Singh (2016) and Anzoategui et al. (2017) describe the interaction between endogenous innovation and nominal rigidities. However, none of these papers analyzes firm heterogeneity, which is an important dimension due to the non-linear effects of collateral constraints. Ates and Saffie (2016) and Schmitz (2017) do include firm heterogeneity in a model with creative destruction and aggregate financial shocks, but they do not consider the collateralizability of different types of capital nor the effects of financial shocks on incumbent firms' incentives to invest and default.

In the data, incumbent intangible investment is also sensitive to financial conditions, and it accounts for the largest share of total intangible investment. Moreover, contrary to what simpler innovation models would predict, entry and exit rates are negatively correlated over the cycle. Both in Spain and in the U.S., the Great Recession brought a surge in exit rates, together with a moderate fall in entry rates. To the best of my knowledge, this paper is the first to analyze the response of intangible investment to financial shocks in a dynamic framework with endogenous default. A second contribution of this paper is modeling financial shocks as an increase in the price of aggregate risk, as opposed to the risk-free rate

CInternational Monetary Fund. Not for Redistribution 
or the compensation for default risk. This distinction is crucial to explain the propagation of financial shocks through the channels related to the properties of intangibles, and would be missed by a linearized model. Finally, the presence of these additional propagation channels allows me to replicate the cyclical behavior of output without assuming excessive levels of leverage for productive firms. As discussed in Shourideh and Zetlin-Jones (2017), previous quantitative work struggles to reconcile the observed large effects of financial shocks with the low levels of external-financing dependence in the data.

The empirical method in this paper, structural estimation of a heterogeneous-firm model by the simulated method of moments, is similar to the one in Hennessy and Whited (2007), Acemoglu et al. (2013) and Catherine et al. (2017). The work which is methodologically closer is Eisfeldt and Papanikolaou (2013), which estimates a structural model where firms can invest in tangible and organizational capital, and shows that firms with a larger proportion of measured organizational capital pay a significantly larger equity premium. Nevertheless, Eisfeldt and Papanikolaou (2013) do not study the effects of aggregate shocks nor debt financing.

There is a series of reduced-form corporate finance studies that corroborate some of the my model's predictions. Benmelech and Bergman (2009) show that asset collateralizability decreases loan spreads and increases lending volumes to firms within the airline industry. With a sample of listed firms, Falato et al. (2013) provide evidence that investment in intangible assets is correlated with own-resource accumulation, which suggests the presence of stricter external financing constraints for those assets. Aghion et al. (2012) show that French firms which are more credit constrained tend to have a more procyclical $R \& D$ expenditures pattern. In close connection to my results, De Ridder (2016) and Duval et al. (2017) document that firms exposed to more severe financial shocks applied larger cuts to intangible investment and experienced persistently lower productivity after the Great Recession.

\section{Model}

I develop a corporate-sector model with heterogeneous firms that can invest in physical capital as well as in intangible capital. Private intangible capital diffuses to other firms (or depreciates) at a random firm-idiosyncratic rate, which is the source of firm heterogeneity. Investments are financed by internal equity and defaultable debt. Firms maximize shareholder value taking aggregate prices as given. The corporate sector is subject to aggregate shocks to revenues and state prices. The model focuses on short and medium-run fluctuations, abstracting from the determinants of long-run growth. This framework is relevant to any open sector where intangible investment has a significant role and debt financing is 
prevalent, as is the case for manufacturing in most European and advanced Asian economies.

\subsection{Agents and Maximization Problem}

\subsubsection{General Framework}

This is a model of firms operating in a small open economy. Each firm produces one differentiated variety in monopolistic competition. World output $Y_{t}^{w}$ is defined as a CES composite of the $N^{w}$ final good varieties that can be produced in some country:

$$
Y_{t}^{w}=\left(\sum_{j=0}^{N^{w}}\left(y_{t}^{j}\right)^{\frac{\sigma-1}{\sigma}} \mathrm{dj}\right)^{\frac{\sigma}{\sigma-1}}
$$

where $\sigma$ is the elasticity of substitution across varieties and $y_{t}^{j}$ is the value added output of each variety in the global economy. Throughout the paper, variables defined at the firm level are in lowercase letters, whereas aggregate variables are in caps.

Real global income $D_{t}$ is exogenous and equal to a deterministic component, growing at rate $g \geq 0$, multiplied by a stochastic stationary component. As discussed below, variables in this model fluctuate around a balanced growth path (BGP) growing at rate $g$, so all variables with a trend can be normalized to the deterministic component of global income. Given a level of global income, world consumers maximize the aggregate output composite $Y_{t}^{w}$ choosing the quantity of each variety $y_{t}^{j}$ that they purchase in each period, and taking individual prices $p_{t}^{j}$ as given. From the demand function of consumers, we obtain that the revenue for an individual firm as a function of its output $y_{t}^{j}$ is given by

$$
p_{t}^{j} y_{t}^{j}=\left(D_{t}\right)^{\frac{1}{\sigma}}\left(y_{t}^{j}\right)^{\frac{\sigma-1}{\sigma}} .
$$

For the purposes of the model, shocks to global income $D_{t}$ matter insofar as they affect the revenue function of domestic firms. A positive shock to global income raises revenues both because of the direct increase in the price, given by $\left(D_{t}\right)^{\frac{1}{\sigma}}$, and because of the endogenous increase in the quantity produced, given by $\left(y_{t}^{j}\right)^{\frac{\sigma-1}{\sigma}}$.

The Spanish manufacturing sector consists of a collection of firms operating in this environment, i.e., selling to global consumers, and taking aggregate prices as given. The maximum number of varieties $N$ that can be produced in the domestic economy is constant and $N \ll N^{W}$. 


\subsubsection{Production Technology}

Henceforth, I avoid time and firm indexes whenever they are not strictly necessary. Each individual firm uses labor $l$, physical or tangible capital $k$ and intangible capital to produce output. I denote the private stock of intangible capital in a firm by $a$ and the public stock of intangible capital, taken as given by individual firms, by $A$. Production requires payment of a fixed cost $T$ every period. The production function

$$
y=A^{1-\alpha-\beta} a^{\beta} k^{\alpha} l^{1-\alpha}
$$

is assumed to be Cobb-Douglas with $\alpha, \beta \in(0,1)$ and $\alpha+\beta<1$. Note that this specification features constant returns to scale in physical capital and labor, which is consistent with the usual replication argument formulated in the Neoclassical Growth Model, and increasing returns to scale once we take into account investment in private intangible capital. The underlying assumption is that intangible capital is not consumed as a firm opens an additional production unit. I also assume that the decreasing returns generated by the revenue function (2) dominate the private increasing returns in the production function (3), i.e., $(1+\beta)\left(\frac{\sigma-1}{\sigma}\right)<1$. This ensures that the optimal firm size from the private point of view is a real number. The exponent on $A$ is such that the exponents on all the reproducible stocks of capital $(k, a$ and $A$ ) sum up to one. This implies that the production function simplifies to the AK Growth Model from the point of view of a social planner that takes into account the externalities in intangible investment and employs a fixed labor supply.

Labor contracts last one period and pay a wage $W$. Firms can invest in physical capital and private intangible capital. The accumulation function for physical capital includes a standard adjustment cost function $\phi_{k}($.$) :$

$$
k^{\prime}=\left(k+i_{k}-\phi_{k}\left(\frac{i_{k}}{k}\right) k\right)\left(1-\delta_{k}\right)
$$

where $k^{\prime}$ denotes physical capital in the next period, $\delta_{k}$ is the depreciation rate of physical capital and $i_{k}$ is investment in physical capital.

The timing convention that depreciation affects current investment facilitates comparability with the accumulation of private intangible capital. The difference in the accumulation function of intangibles is the addition of a depreciation shock $z^{\prime}$ :

$$
a^{\prime}=\left(a+i_{a}-\phi_{a}\left(\frac{i_{a}}{a}\right) a\right)\left(1-\delta_{a} z^{\prime}\right),
$$

where $a^{\prime}$ denotes private intangible capital in the next period, $\delta_{a}$ is the average depreciation 
rate of intangible capital and $i_{a}$ is investment in intangible capital formation (or adoption).

The adjustment cost function takes a quadratic form

$$
\phi_{x}\left(\frac{i_{x}}{x}\right)=\eta_{x}\left(\frac{\left(i_{x} / x\right)-\left(\delta_{x} / 1-\delta_{x}\right)}{1+\left(\delta_{x} / 1-\delta_{x}\right)-\eta_{x}}\right)^{2}
$$

where $x=\{k, a\}$ indexes the two types of capital and $\eta_{x}$ is a parameter. This parametrization ensures that the cost for a firm that maintains its level of type- $x$ capital constant is zero. The adjustment cost captures the fact that capital formation may be firm-specific up to a certain degree. Negative investment rates, i.e., transformation of capital into consumption goods, are possible as long as there is enough capital to divest, i.e., $x+i_{x}-\phi_{x}\left(\frac{i_{x}}{x}\right) x \geq 0$.

The shock $z^{\prime}$ is an exogenous firm-idiosyncratic random variable which evolves according to a $\log$-normal $\mathrm{AR}(1)$ process bounded above by $1 / \delta_{a}$,

$$
\log \left(z^{\prime}\right)=\min \left\{\rho \log (z)+\nu, \log \left(\frac{1}{\delta_{a}}\right)\right\}, \quad \nu \sim \mathrm{N}(0, \theta), \quad \rho \in[0,1)
$$

and the process is normalized to have mean one. The current realization $z^{\prime}$ is not known when the firm makes its investment, hiring and production decisions. The value of $z$ can be interpreted as the inverse of the creativity of a firm. Firms with lower $z$ expect lower depreciation for their intangible investment. Presumably, more creative or advanced knowledge takes more time to depreciate and is harder to imitate by competitors, providing a longer-lasting competitive advantage to the owner.

The idiosyncratic shock serves two purposes in the model. First, it generates a nondegenerate distribution of tangibility ratios across firms, as higher expected depreciation disincentivizes intangible investment. Second, it leads to realistic default rates in equilibrium. The assumption that $z^{\prime}$ is not known when firms invest increases the average default probability (when $z^{\prime}$ becomes unexpectedly high) and avoids extreme investment patterns that would otherwise arise due to linearity in the depreciation term in equation (5).

The private depreciation rate of intangible capital $\delta_{a} z^{\prime}$ does not only include technological depreciation, but also spillovers to other firms. A fraction $\kappa \in(0,1]$ of a firm's private depreciation of intangible capital diffuses to the rest of firms in the economy every period, while the remaining fraction is technological depreciation. ${ }^{1}$ Both forms of private depreciation, diffusion and technological depreciation, imply the loss of the depreciated stock of intangible capital for the original firm.

\footnotetext{
${ }^{1}$ Citations of patents registered by other firms or geographical clustering of innovative firms are two visible consequences of the presence of intangible capital spillovers. Bloom et al. (2013) show evidence that, in the U.S., the social return to firm R\&D is two to three times the private return.
} 
Consistent with the interpretation of private depreciation of intangibles partly as spillovers to the rest of firms, the accumulation function for the public stock of intangible capital is

$$
A^{\prime}=\left(\frac{F-A}{A}\right) \kappa \delta_{a} \bar{a}+A
$$

where $A^{\prime}$ denotes public intangible capital in the next period, $F$ is the world technology frontier and $\bar{a}$ is the cross-firm average of the term $\left(a+i_{a}-\phi_{a}\left(\frac{i_{a}}{a}\right) a\right) z^{\prime}$. Public intangible capital $A$ accumulates with the average diffusion flows of private intangible capital $\kappa \delta_{a} \bar{a}$, and is not subject to technological depreciation. Yet, to keep the model stationary, the term $\left(\frac{F-A}{A}\right)$ introduces a force for mean reversion to the global technological frontier $F$, which grows exogenously at rate $g .^{2}$

In this model, fundamental parameters only affect the output level of a country with respect to the frontier, but not its long-run output growth rate. All the stock variables in the model grow at rate $g$ in the long run. I normalize $F$ so that in the BGP $\frac{F-A}{A}=1$, and thus $A=\frac{\kappa \delta_{a} \bar{a}}{g}<F$ for any parametrization with $g>0$. Thus, the public stock of knowledge $A$ never reaches the global frontier $F$. We can think of $F$ as the level of theoretical research that no firm has implemented yet. If for some reason domestic diffusion flows were interrupted, $A$ would gradually drift away from the frontier, so the effective social depreciation rate of public intangible capital is $g$.

The fraction $\kappa$ that spills over determines the BGP level of $A$. However, as long as $\kappa$ is strictly positive, the value of $\kappa$ does not have any effect on the cyclical behavior of the economy. Given the Cobb-Douglas form of the production function, only relative changes over time in $\bar{a}$ matter. Since the focus of this paper are the fluctuations of the domestic economy with respect to the trend, henceforth I assume $\kappa=1$. The quantitative analysis in Section 6 also considers the case without any spillovers, assuming that $A$ grows exogenously at constant rate $g$.

\subsubsection{Exit and Entry}

Firm exit and entry are endogenous. Firms can decide to liquidate production and exit by divesting all their capital stocks. From equations (4), (5) and (6), the fraction of capital $x$ lost in adjustment (or divestment) costs when a firm liquidates production is $\eta_{x}$, since in that case $i_{x}=-\left(1-\eta_{x}\right) x .^{3}$

There are as many potential entrants as potential varieties in the domestic economy $N$,

\footnotetext{
${ }^{2}$ This avoids the possibility of divergent paths for the growth rates of the domestic and the global economy, which would be at odds with the high degree of convergence observed across developed economies, particularly within the E.U.

${ }^{3}$ This result assumes that liquidation is immediate, and so depreciation does not kick in.
} 
but entrants can only grab varieties of exited firms. Each potential entrant is endowed with initial equity (i.e. negative debt) $e_{0}=-b_{0}>0$ and decides whether to pay the entry cost $\gamma e_{0}$ after observing its initial realization of the idiosyncratic shock $z_{0}$, which is drawn from the stationary distribution of $z$. If there are less idle varieties than potential entrants willing to enter, I assume that entrants with lower values of $z_{0}$ have priority. If a potential entrant decides to enter, it can use its initial equity net of the entry cost to invest in the two types of capital $k$ and $a$ and start production. Otherwise, it enjoys the outside value $e_{0} \cdot{ }^{4}$

\subsubsection{Firm Financing}

Once a firm has entered, it can finance investments internally with accumulated profits, and it can also issue a defaultable one-period bond $b$ at price $q^{b}$. Bonds are traded in a competitive market where investors can observe all the current characteristics of each firm, as well as the aggregate state.

Bond contracts are structured as follows. Firms receive a quantity $q^{b} b^{\prime}$ of the consumption good in the current period and must repay $b^{\prime}$ in the following period if they want to avoid liquidation. The price $q^{b}$ can depend on the aggregate and firm idiosyncratic states, as well as on the current actions of the firm, which are observable. Firms also have the option to default and liquidate production. ${ }^{5}$ From the amount of assets remaining after divestment costs, the maximum that debtholders can recover is a fraction $\psi_{k}$ of tangible assets and a fraction $\psi_{a}$ of intangible assets. The rest is captured by the owners. Formally, in case of liquidation, debtholders recover

$$
\min \{\bar{b}, b\}
$$

where the upper bound is

$$
\bar{b} \equiv\left(1-\eta_{k}\right)\left(1-\psi_{k}\right) k+\left(1-\eta_{a}\right)\left(1-\psi_{a}\right) a,
$$

and the remaining value captured by owners is

$$
\left(1-\eta_{k}\right) k+\left(1-\eta_{a}\right) a-\min \{\bar{b}, b\}
$$

\footnotetext{
${ }^{4} \mathrm{I}$ assume that the depreciation rate of initial (age-zero) tangible and intangible investment is equal to $\delta_{k}$ and $z_{0} \delta_{a}$ respectively, and that initial investment is subject to the same proportional adjustment costs as a liquidating firm: $\eta_{k}$ and $\eta_{a}$.

${ }^{5}$ For simplicity, I assume that default inevitably leads to liquidation, even if in some cases debt restructuring could be Pareto improving due to the presence of real liquidation costs. I proceed thusly since 95 percent of companies that start insolvency procedures in Spain end up in liquidation, according to a report by PricewaterhouseCoopers.
} 
The relevant assumption for the main theoretical mechanism to operate, which is confirmed by my estimation results, is that $\psi_{k}>\psi_{a}$, i.e. physical capital is easier to seize by debtholders in case of default than intangible capital.

Firms can also save in a risk free-bond (setting $b<0$ ), which returns a net risk-free rate $R_{f}$ and bears no divestment cost. I assume that there is no conflict of interests between managers and owners or shareholders. Owners can trade equity in a competitive stock market, but the cost of new equity issuances is prohibitive.

\subsubsection{Aggregate Shocks}

Since the ultimate goal of this model is to understand the effects of different types of shocks, I consider three possible aggregate states: normal, non-financial shock and financial shock. Formally, the aggregate state can take the values $M_{t}=\left\{M^{n}, M^{c}, M^{f}\right\}$ and it evolves over time as a Markov Chain with transition matrix $\Pi_{M}$. The aggregate state determines two aggregate variables: global income $D(M)$ and the equity premium in global financial markets $R_{e}(M)$. Both financial and non-financial shocks feature lower global income than a normal state, which reduces the revenues of domestic firms. The qualitative difference between the two types of shocks is that in a financial shock state the equity premium is larger than in the other two states: $R_{e}\left(M^{n}\right)=R_{e}\left(M^{c}\right)<R_{e}\left(M^{f}\right) .{ }^{6}$ Section 3.2.2 explains how the equity premium affects firm financing.

Real wages are roughly acyclical in Spanish manufacturing, so I normalize the level of wages (relative to the BGP) to $W=1$ for all states. ${ }^{7}$ Section 4.1 describes in detail the estimation of the exogenous variables $\Pi_{M}, D(M)$ and $R_{e}(M)$, as well as the risk-free rate $R_{f}$, with aggregate European Union (E.U.) data.

\subsubsection{Asset Pricing}

The possibility for firms to trade equity implies that all agents are perfectly diversified against idiosyncratic risk, and therefore only price aggregate risk. ${ }^{8}$ Hence, we can define a unique matrix of state prices $S$ for all agents, where each entry in $S$ indicates the price of next period's state $M^{\prime}$ conditional on the current state $M$. The vector $S(M)$ can be used to

\footnotetext{
${ }^{6}$ Muir (2017) provides empirical support for this qualitative assumption, as it shows that the expected equity premium increases in financial crises, but not in other types of crises.

${ }^{7}$ Since labor flows in and out of the manufacturing sector, endogenizing wages would require modeling other sectors in the economy (as well as wage-setting frictions and unemployment). However, given the acyclicality of wages in the sample of study, this is not necessary for the purposes of this paper. Wage data is obtained from the National Statistics Institute.

${ }^{8}$ In this model, assuming that agents were also subject to acyclical idiosyncratic risk would not have a first-order effect on the aggregate cyclical results, as the fall in aggregate investment in response to a financial shock is mainly due to the contraction in the supply of credit to firms.
} 
price any asset in the economy at aggregate state $M$. Section 4.1.1 shows how we can infer the matrix of state prices directly from the data on the risk-free rate $R_{f}$, equity premium $R_{e}(M)$ and realized market returns $x_{m}$. This model-free approach avoids specifying a utility function and is consistent with different underlying asset-pricing models that explain why the equity premium is higher in financial recessions. Changes in $S$ over time could reflect changes in beliefs about the distribution of consumption across aggregate states or changes in risk preferences.

\subsubsection{Dynamic Firm Problem}

To recap, the state variables in the firm's problem are physical capital $k$, private intangible capital $a$, public intangible capital $A$, the stock of debt $b$, the idiosyncratic shock $z$, the aggregate shock $M$, and whether each variety is being produced or not.

The value of an incumbent firm for its owners

$$
V(k, a, A, b, z, M)=\max \{\mathcal{C}(k, a, A, b, z, M), \mathcal{L}(k, a, b)\}
$$

is the maximum between the continuation and liquidation values.

The continuation value $\mathcal{C}$ is the optimum of the following problem. Firms choose investments in the two assets $i_{k}$ and $i_{a}$, labor $l$ and debt issuances $b^{\prime}$ to maximize dividends $d$ plus next period's discounted value,

$$
\mathcal{C}=\max _{\left\{i_{k}, i_{a}, l, b^{\prime}\right\}} d+\sum_{M^{\prime}} S\left(M, M^{\prime}\right) \mathbb{E}\left[V\left(k^{\prime}, a^{\prime}, A^{\prime}, b^{\prime}, z^{\prime}, M^{\prime}\right)\right]
$$

subject to i) the no-equity-issuance condition

$$
d \geq 0
$$

equivalent to requiring non-negative dividends, and ii) the laws of motion for capital stocks in equations (4), (5) and (8), and the evolution for the idiosyncratic shock in equation (7). Note that next period's value is discounted with the vector of state prices $S$ in each future state $M^{\prime}$, which is a function of the current state $M$. The expectation operator $\mathbb{E}[\cdot]$ is taken over the p.d.f. of the idiosyncratic shock $z$.

Dividends are equal to net profits $v$ plus debt issuances minus debt repayment

$$
d=v+q^{b} b^{\prime}-b
$$


Net profits are defined as revenues minus labor costs, investment expenditures and the fixed production cost

$$
v \equiv(D(M))^{\frac{1}{\sigma}} y^{\frac{\sigma-1}{\sigma}}-W(M) l-i_{k}-i_{a}-T .
$$

Output $y$ is determined by the production function in equation (3).

The liquidation value is the amount captured by owners in case of liquidation

$$
\mathcal{L}=\left(1-\eta_{k}\right) k+\left(1-\eta_{a}\right) a-\min \{\bar{b}, b\}
$$

If there is no default, i.e. if the maximum collateralizable amount $\bar{b}$ is larger than outstanding debt $b$, owners recover the post-liquidation value of assets after repaying $b$ (or after cashing in $b$ if $b<0$ ). If instead $\bar{b}<b$, owners only repay $\bar{b}$ and can divert a fraction of the post-liquidation value of assets, as explained in Section 3.1.4.

Assuming that entrants do not find it profitable to invest any amount in risk-free bonds, which will be the case in the equilibrium of the estimated model, the value for entrant firms is given by the solution to the following problem:

$$
\max _{k_{0}, a_{0}} V\left(k_{0}, a_{0}, A, 0, z_{0}, M\right)
$$

subject to no debt issuances in period zero

$$
\frac{k_{0}}{1-\delta_{k}}+\frac{a_{0}}{1-z_{0} \delta_{a}}=-(1-\gamma) b_{0}
$$

This is, firms only start issuing debt after incorporating.

\subsection{Equilibrium}

\subsubsection{Definition}

A competitive equilibrium is defined by a debt price $q^{b}$, quantities $\left\{k, a, A, b, i_{k}, i_{a}, l\right\}$, and a decision $\{\mathcal{C}, \mathcal{L}\}$, for each period of the lifetime of each firm, as well as the number of varieties produced in each period, such that: i) firms maximize their value given the debt supply schedule $q^{b}$, the idiosyncratic shock $z$, global income $D(M)$, the vector of state prices $S(M)$, wages $W$, the public stock of intangibles $A$ and the no-equity-issuance condition; ii) investors price firm debt competitively given $S(M)$; and iii) the laws of motion for $k, a$ and $A$ in equations (4), (5) and (8) are satisfied. 
Note that the only endogenous aggregate variable is $A$. Financial markets are globally integrated, and labor can flow in and out of unemployment or other sectors in the economy. Given the small open economy assumption that the Spanish manufacturing sector does not affect global prices or wages, I do not need to impose market clearing conditions.

Appendix A.1 lists the steps for the numerical computation of the equilibrium.

\subsubsection{Characterization}

Labor The optimality condition for labor is purely static. Optimal labor can be solved for analytically from the firm first order condition

$$
l=\left[\frac{(\sigma-1)(1-\alpha)}{\sigma W} D^{\frac{1}{\sigma}}\left(A^{1-\alpha-\beta} a^{\beta} k^{\alpha}\right)^{\frac{\sigma-1}{\sigma}}\right]^{\frac{\sigma}{\sigma-(\sigma-1)(1-\alpha)}}
$$

Debt issuances and debt prices Let us now consider the intertemporal optimality conditions. A useful feature of the equilibrium is that it is never optimal for a firm to pay out any positive dividends. Firm owners have the same pricing function as external investors and can always accumulate risk-free bonds in the firm, which is a costless way to reduce the probability of facing high external financing costs in the future. Hence, in equilibrium $d=0$, so we can use the definition of dividends in equation (14) to obtain an expression for debt issuances

$$
b^{\prime}=\left(q^{b}\right)^{-1}(b-v)
$$

Given the optimal labor choice, debt issuances $b^{\prime}$ are pinned down by investment in the two types of assets $i_{k}$ and $i_{a}$, which determines the equilibrium price of a firm's debt $q^{b}$ and net profits $v$.

From investors optimality, the equilibrium price of debt is given by

$$
q^{b}=\sum_{M^{\prime}} S\left(M, M^{\prime}\right) \mathbb{E}\left[\mathcal{R}\left(k^{\prime}, a^{\prime}, A^{\prime}, b^{\prime}, z^{\prime}, M^{\prime}\right)\right]
$$

where the repayment rate $\mathcal{R}$ is

$$
\mathcal{R}= \begin{cases}1 & \text { if } \mathcal{C} \geq \mathcal{L} \\ \min \left(\frac{\bar{b}}{b}, 1\right) & \text { if } \mathcal{C}<\mathcal{L}\end{cases}
$$

This is, the repayment rate is equal to one if the firm does not exit (liquidate production), 
Figure 2: Debt Interest Rate by Investment Tangibility

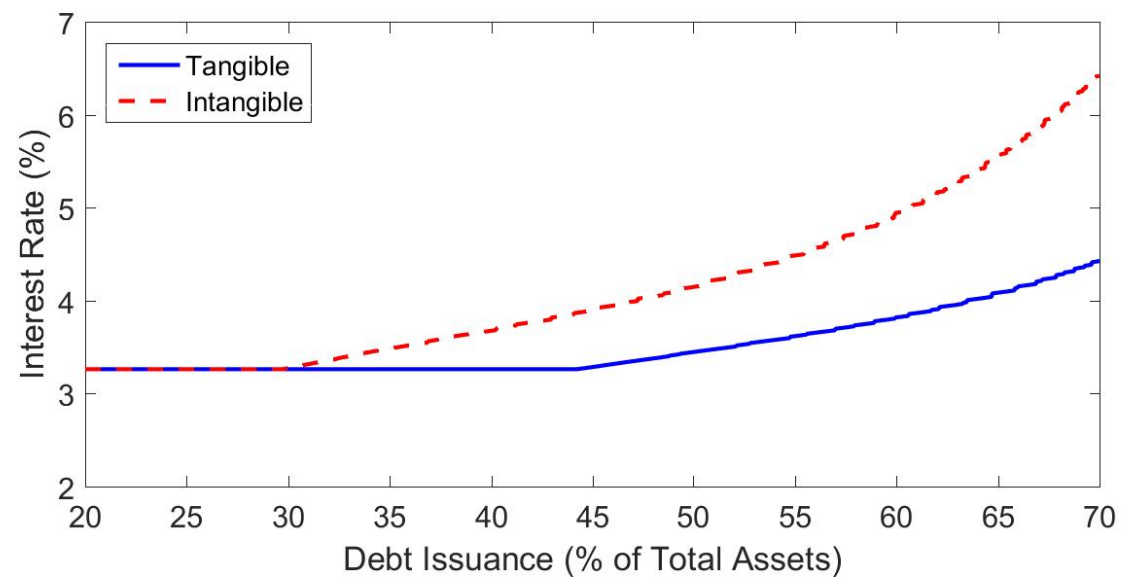

and equal to the maximum amount debtholders can seize from the firm's assets divided by total outstanding debt otherwise.

Therefore, debt prices for each firm depend on two components. First, the expected repayment rate in the next period. Second, the covariance of the repayment rate with the aggregate state (i.e. the market beta of a firm's debt), through the vector of state prices $S(M,$.$) . The first component would also be present in a model with risk-neutral agents.$ The importance of the second component is increasing in the price of aggregate risk in global markets $R_{e}$ (see mapping in Section 4.1.1).

To illustrate the relationship between the cost of debt financing and asset tangibility, Figure 2 plots the competitive debt interest rate $\left(1 / q^{b}-1\right)$ as a function of debt issuances for two different firms. Both firms start with zero outstanding debt, an average level of tangible and intangible capital, $z=1$, and are in a normal state $\left(M=M^{n}\right)$. However, I impose that in the current period one of the two firms only invests in tangible capital and the other one only in intangible capital. The amounts invested are kept fixed for each firm. The figure shows that for the two firms, the interest rate is increasing in the amount of debt issuances $b^{\prime}$. For values of $b^{\prime}$ below $\bar{b}^{\prime}$, the probability of default is zero and thus the inverse loan supply curve is perfectly flat. As $b^{\prime}$ grows, the default probability increases and the repayment rate becomes more correlated with the aggregate state, so the interest rate goes up. However, the supply curve for the firm investing in intangibles is steeper. For any given amount of debt issuances, as soon as creditors expect a nonzero default probability, the intangible-intensive firm has to pay a higher interest rate. This is due to its lower repayment rate in case of default and higher covariance between the repayment rate and the aggregate state price. Hence, when the price of aggregate risk surges in a financial shock state, both curves will steep up, but the one for the firm investing in intangibles will do so in a greater proportion, as its debt is expected to repay disproportionately less in bad states. 
Figure 3: Firm Life Cycle

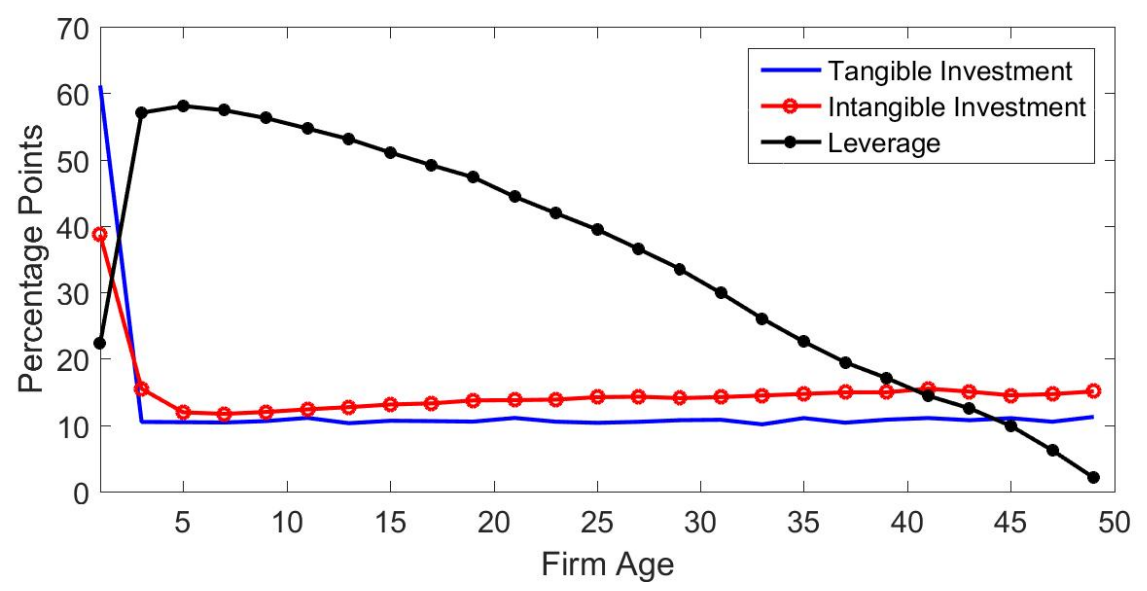

Notes: In this figure, tangible and intangible investment are rates to tangible and intangible capital respectively. Leverage is debt over total assets. All variables are biannual means for comparability with the data (Figure 12).

Investment in physical and intangible capital The equilibrium values for investments in physical capital $i_{k}$ and in intangible capital $i_{a}$ are obtained by numerical optimization, as explained in Appendix A.1. However, we can gain some intuition by looking at the firm life-cycle pattern. Figure 3 shows average tangible and intangible investment rates ( $i_{k} / k$ and $i_{a} / a$ ) and the leverage ratio, defined as debt over total assets $\left(\frac{b}{k+a}\right)^{+}$, as a function of a firm's age. Firms start small and with no debt. To reach their optimal mature size, they invest at high rates when they are young, issuing bonds to finance investment expenditure. This progressively increases the leverage ratio until the firm is large enough to start financing internally and begins to deleverage. Mature firms feature intangible investment rates higher than tangible investment rates because the private depreciation rate of intangible capital is larger (see estimated parameters in Table 2). However, the relationship flips for younger firms. This is due to both the more stringent financial constraints and higher adjustment costs affecting intangible investment. The data on the firm life cycle in Appendix A.4 features the same qualitative patterns.

Another interesting comparative static is the dependence of investment rates on the outstanding leverage of a firm. When leverage is very high, external financing becomes expensive and firms have to reduce their investment rates, particularly on intangible capital, as implied by Figure $2 .{ }^{9}$

\footnotetext{
${ }^{9}$ This is the force that dominates on the aggregate. However, investment rates are not monotonically decreasing on the leverage of a firm. For a region around moderate leverage levels, higher leverage can induce higher investment rates due to the real option provided by the possibility for owners to default and capture part of the firm's assets.
} 
Exit and entry By assumption, default leads to exit (liquidation), but exit can also occur in the absence of default. Given the process specified for the idiosyncratic shock $z$, all firms have a positive probability to lose all their stock of private intangible in each period, which leads to firm exit. ${ }^{10}$

The only dimension of heterogeneity among entrants is the initial value of the intangible capital depreciation shock $z_{0}$, which is informative about future shocks due to its positive autocorrelation. This implies that in each period there will be a threshold $z_{0}$ above which potential entrants decide not to enter. Since entrants face higher adjustment and external financing costs, they will tend to have lower values of $z$ (higher creativity) than the average firm.

The maximum number of varieties that can be produced, both in the domestic and in the world economy, is fixed, so long-run growth is not driven by variety creation. However, the actual number of varieties produced fluctuates over the business cycle, according to difference between entry and exit flows. Adverse aggregate shocks, which typically entail negative net entry, may be followed by a series of periods with a lower number of varieties produced in equilibrium.

\subsection{Amplification and Persistence of Financial Shocks}

We are now ready to analyze how the model generates additional amplification and persistence of the GDP deviation after a financial shock, compared to a non-financial shock. The channels are related to the particularities of intangible capital modeled in this paper: lower collateralizability, spillovers and adjustment costs.

Lower collateralizability and financial constraints In general, all firms have higher expected default rates in shock states. However, as intangible assets are less collateralizable $\left(\psi_{k}>\psi_{a}\right)$, expected repayment rates of intangible-intensive firms are comparatively low in shock states. Since investors price aggregate risk and $q^{b}$ is firm-specific, firms face higher debt financing costs for intangible investment (Figure 2). This differential is exacerbated in financial shock states, when the discount on aggregate risk is higher, compared to non-financial shock states. Yet, convex adjustment costs on intangible investment and complementarity in the production function make it inefficient for firms to concentrate the

\footnotetext{
${ }^{10}$ Since investment costs tend to infinity when $a$ tends to zero, and the production function is CobbDouglas, firms that have lost all their intangibles do not find it optimal to continue producing. Even if $a$ is positive, for a bad enough idiosyncratic shock, firms may find it optimal to exit in the absence of default due to the presence of the fixed production cost $T$.
} 
adjustment on intangible capital alone. ${ }^{11}$ The financial constraint thus transmits to physical capital investment and labor. In addition, the higher price of aggregate risk leads to an increase in default and exit rates, especially for intangible-intensive firms, as it becomes harder to refinance outstanding debts. Since in this model entrants do not automatically replace exiters, the consequent fall in the number of varieties produced further deepens the GDP fall in financial shock states. In sum, financial constraints on intangibles provide amplification through both the intensive (investment) and the extensive (exit) margin. In turn, these two margins create the following two channels for persistence.

Gradual spillovers and social depreciation In any model with capital accumulation, persistence after aggregate shocks is larger when capital depreciation rates are low, as stocks take longer to recover. Here, as discussed in Section 3.1.2, gradual spillovers from firms to the public stock of intangible capital imply a lower social depreciation rate for intangibles. Thus, financial shocks propagate over time because increases in the price of aggregate risk affect investment in the capital stock with lower social depreciation disproportionately more.

Adjustment costs and life-cycle growth From the estimation results (Table 2), I obtain that investment in intangible capital has higher adjustment costs, i.e., $\eta_{a}>\eta_{k}$. We have seen how financial shocks lead to higher default and exit rates. Exiters are eventually replaced by entrants, which start small. Since adjustment costs are higher for intangibles, entrants take more time to reach the optimal level of intangible capital than that of tangible capital. The combination of higher exit rates and adjustment costs for intangible-intensive firms implies that the aggregate stock of intangibles also takes longer to recover on the extensive margin. As a result, this last channel adds to the persistence of financial shocks.

The literature on balance sheet constraints emphasizes how financial frictions can amplify any shock affecting firms' net worth through the financial accelerator channel (see Bernanke et al. (1999)). This mechanism is also present in my model. However, the novel result here is that shocks of different nature lead to qualitatively different responses of the real economy.

This model does not produce a persistent response after financial shocks simply because there is an increase in average interest rates, but because the discount on aggregate risk rises and intangible-intensive firms carry more aggregate risk. An increase in the risk-free rate would have very similar effects to a non-financial shock, or to any shock purely reducing firm profits, as it would affect investment in tangibles and in intangibles in the same way.

\footnotetext{
${ }^{11}$ In the data, a sizable fraction of intangible investment is in the form of wages to high-skilled workers, whose quantity cannot be quickly adjusted in response to cyclical shocks.
} 


\section{Data}

Let us proceed to the quantitative part of the paper. This section describes the data used to identify aggregate shock processes and structural parameters of the model. Aggregate shocks are estimated with aggregate E.U data, while the estimation of the rest of model parameters is based on Spanish manufacturing firm-level data. In line with the model assumptions, the Spanish manufacturing sector features a high degree of trade and financial openness, relevant intangible investment levels, and a central role for debt financing (the value-added share of listed firms is only 14 percent and external private equity is negligible).

\subsection{Aggregate Shocks}

Table 1 contains the values of the aggregate shocks, as well as the matrix of transition probabilities for $M$ and the matrix of state prices $S$. I estimate the exogenous aggregate shock process with data from the E.U., which is by far Spain's main trading and financial partner. The Spanish manufacturing sector, which accounts for about one fifth of total Spanish value added, is not large enough to significantly alter E.U. averages. The only aggregate variable which is estimated with Spanish manufacturing data are wages, as the European labor market is not effectively integrated.

The first step is to classify each of the years spanned by the firm-level dataset (1990-2013) into one of the three possible aggregate states: normal, non-financial shock and financial shock. The variable used to estimate the global income shock is real GDP in the E.U. excluding Spain. ${ }^{12}$ Normal years are defined as those with GDP growth weakly higher than the period's average: 2 percent. The rest are "shock" years. Due to the asymmetry in business cycle fluctuations, there are more normal than shock years. To classify shock years into financial and non-financial, I use the expected equity premium in the E.U. stock market. A year is classified as a financial shock if in any of the years in the same shock sequence the expected equity premium was higher than 10 percent. ${ }^{13}$ According to this classification algorithm, the non-financial shock periods are 1981-1983, 1992-1994 and 2003-2004. ${ }^{14}$ The

\footnotetext{
${ }^{12}$ Exports account on average for 29 percent of Spanish manufacturing sales (during 1990-2013). An alternative method to estimate aggregate income shocks would be to also include the fall in Spanish internal demand, although that would compromise the exogeneity of the shock. The alternative would yield only slightly larger shocks: 0.97 and 0.89 in a non-financial and financial crisis respectively.

${ }^{13}$ E.U. real GDP data is from the IMF World Economic Outlook Database (October 2014). I use data for the period 1981-2013 (instead of 1990-2013) to increase precision of the transition probabilities matrix. To estimate the risk-free rate and the equity premium, I use data on German federal-security nominal rates and inflation from the Bundesbank, and equity returns data from the STOXX Europe Total Market Index (TMI).

${ }^{14}$ Given that stock market data is only available since 1992, I follow Reinhart and Rogoff (2009) to classify the 1981-1983 crisis as non-financial. For the rest of episodes, my classification based on the expected equity
} 
Figure 4: Expected Equity Premium and Debt Rates
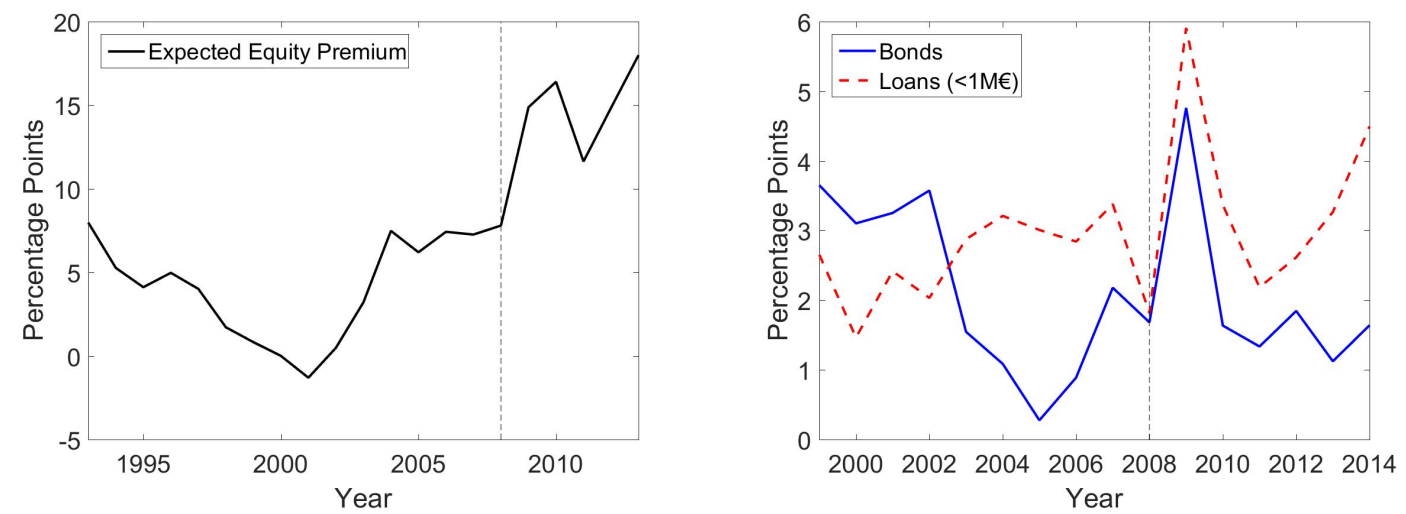

Notes: Samples: European Total Market Index (left) and Spanish non-financial firms (right). Sources: Stoxx (stock index), Dealogic (bonds) and ECB (loans).

only financial shock is the Great Recession, 2009-2013.

The expected equity premium is computed a la Cochrane (1999), with a regression of realized returns on the one-year-lagged dividend-price ratio. Figure 4 (left panel) shows the time series of the expected equity premium. The Great Recession is accompanied by a large and persistent increase in expected returns, which translated into higher real interest rates for the debt of Spanish non-financial firms, both for corporate bonds and for corporate bank loans (right panel). ${ }^{15}$ In contrast, the years of the dot-com boom coincide with very low expected returns.

Once the value of $M$ for each year is determined, I estimate the mapping between $M$ and global income $D(M)$ and the equity premium $R_{e}(M)$, as well as the transition matrix $\Pi_{M} . \quad D(M)$ is obtained as the average level of real GDP relative to the 1980-2013 trend for each value of $M$. I normalize $D\left(M^{n}\right)=1$. Global income falls by 2 percent in a nonfinancial shock and by 8 percent in a financial shock. Since the real risk-free rate $R_{f}$ is not significantly correlated with the aggregate state, it set as a constant, equal to 3.3 percent. ${ }^{16}$ $R_{e}(M)$ is obtained as the average expected equity premium in financial shock periods and in the rest of periods. On average, it increases from 4 to 14 percent when the economy enters a financial shock state.

To estimate the transition matrix $\Pi_{M}$, I proceed in two stages due to the limitation of years of data available. Conditional on being in the normal state, I estimate the transition probabilities from my sample of realizations for $M$. For shock states, I also estimate the

premium is perfectly coincident with Reinhart and Rogoff's, which is based on banking crises.

${ }^{15}$ Corporate bond rates are obtained from Dealogic and bank loan rates from the ECB MIR statistics.

${ }^{16}$ The average risk-free rate varies by less than 1 percentual point across aggregate states. 
Table 1: Aggregate Shocks

\begin{tabular}{cccc}
\hline \hline \multicolumn{4}{c}{ Aggregate Shock Values } \\
\hline & normal & non-finan. shock & financial shock \\
\hline global income & 1 & 0.98 & 0.92 \\
equity premium & $4.0 \%$ & $4.0 \%$ & $13.9 \%$ \\
\hline \multicolumn{4}{c}{ Transition Matrix $\left(\Pi_{M}\right)$} \\
\hline \hline & normal' & non-finan. shock' & financial shock' \\
\hline \multicolumn{4}{c}{0.84} \\
normal & 0.11 & 0.05 \\
non-finan. shock & 0.38 & 0.38 & 0.24 \\
financial shock & 0.14 & 0.53 & 0.33 \\
\hline \hline \multicolumn{4}{c}{ State Prices $(S)$} \\
\hline \hline normal & 0.33 & 0.04 & 0.60 \\
non-finan. shock & 0.18 & 0.19 & 0.60 \\
financial shock & 0.02 & 0.09 & 0.85 \\
\hline
\end{tabular}

Notes: In sub-tables two and three, rows indicate the current state $M$ and columns indicate next period's state $M^{\prime}$.

probability of reverting to the normal state directly from the data, but I assume that the probability to transition to the other type of shock is equal to the unconditional frequency of that shock state, divided by the unconditional probability of both shock states. Admittedly, this is not ideal, as my classification algorithm does not allow for transitions between the two shock states. However, imposing no transitions between shock states in the estimation of the transition matrix would be inconsistent with the presence of strictly positive state prices for each future state of the world. In any case, the transition matrix is only necessary to simulate random time series for $M$. The behavior of agents is solely determined by the vector of state prices in each current state.

\subsubsection{State Prices}

To infer state prices from the empirical values of $R_{f}, R_{e}(M)$ and the realized market-returns, for each current state $M$ I use the theorem in financial economics that, under no arbitrage, there exists a vector of positive state prices. This method requires information on the payoff matrix and prices of as many independent assets as states are to be estimated. From the data I can only construct the payoff matrix for two assets, the risk-free bond and the market security. ${ }^{17}$ Hence, I first estimate state prices for a financial shock state and for the two other

\footnotetext{
${ }^{17}$ I do not use information on defaultable debt returns to infer state prices because I do not have data on the recovery rates for debtholders in case of default during the relevant period.
} 
states (normal and non-financial shock) combined. I denote this reduced 2-by-2 matrix of state prices by $\bar{S}$. The price of the risk free-security is given by $\frac{1}{1+R_{f}}$, and the price of the market security by $\frac{1}{1+R_{f}+R_{e}(M)}$. The payoff of the risk-free security, by definition, is 1 in each state of the world. For the market security, I assume that the payoff is $1+m$ in states without a financial shock and $1-m$ in a financial shock state, where $m$ is such that the variance of $\{1+m, 1-m\}$ is equal to the variance of the empirical realized market returns $x_{m} \cdot{ }^{18}$ State prices for these two states are then given by

$$
\bar{S}=\left(\begin{array}{cc}
1 & 1 \\
1+m & 1-m
\end{array}\right)^{-1}\left(\begin{array}{cc}
\frac{1}{1+R_{f}} & \frac{1}{1+R_{f}} \\
\frac{1}{1+R_{f}+R_{e}\left(M^{n}\right)} & \frac{1}{1+R_{f}+R_{e}\left(M^{f}\right)}
\end{array}\right)
$$

Matrix rows correspond to the current state and columns to next period's state. The next step is to obtain an approximated 3-by-3 matrix of state prices $S$ for the three states. To do that, I multiply the state prices in the states without a financial shock by the unconditional probability that each of the two states (normal and non-financial shock) occurs:

$$
S=\left(\begin{array}{cc}
\frac{\pi_{1}}{\pi_{1}+\pi_{2}} \bar{S}_{1} & \frac{\pi_{2}}{\pi_{1}+\pi_{2}} \bar{S}_{1} \quad \bar{S}_{2}
\end{array}\right)
$$

where $\pi=\iota^{\prime} \Pi_{M}$ and $\iota$ is a 3 -by-1 vector of ones. ${ }^{19}$ Table 1 shows the estimated values of $S$. For each current state in the matrix rows, the state prices in the matrix columns sum up to the price of a risk-free bond $\frac{1}{1+R_{f}}$. Their composition varies according to the equity premium. If the economy is currently in a financial shock, the financial shock state next period has a higher state price. Since the financial shock state is associated with a low equity payoff, a high price attached to that state in the next period is consistent with a higher equity premium in equilibrium.

\subsection{Firm-Level Data}

I estimate the rest of model parameters with firm-level data from the Survey on Business Strategies (ESEE in Spanish) and from the Public Registry of Firms (DIRCE in Spanish). ${ }^{20}$ This dataset is a high-quality panel of 1,800 Spanish manufacturing firms from 1990 to 2013

\footnotetext{
${ }^{18}$ The matrix of expected market returns is $x_{m}=\left(\begin{array}{ll}1+R_{f}\end{array}\right) \iota \iota^{\prime}+R_{e} \iota^{\prime}+m \iota\left(\begin{array}{lll}1 & 1 & -1\end{array}\right)$.

${ }^{19}$ This approximation is consistent with the literature on the macroeconomic implications of disaster risk (e.g. Gourio (2012)), which shows that the price of aggregate risk is driven by the valuation of extremely bad events.

${ }^{20}$ The Encuesta sobre Estrategias Empresariales (ESEE) is property of Fundacion SEPI, a government entity related to the Ministry of Industry. Annual reports are available at Fundacion SEPI's website. Fariñas and Jaumandreu (1995) provide a more detailed description of the survey.
} 
which was designed to understand firm strategic behavior. It surveys the whole population of firms with more than 200 employees, including foreign company subsidiaries, and a representative sample of firms between 10 and 200 employees. ${ }^{21}$ The sample covers around 35 percent of value added in Spanish manufacturing, and it includes small and medium enterprises, which account for a large share of the market in Europe, and an even larger share of investment and job creation, but are often left out of empirical corporate finance studies.

This dataset is unique in that it features very detailed information on firms' tangible and intangible investment expenditures, together with financial (complete balance sheet) information and employment. In particular, it contains both the book value of the stock of intangible assets and the flow of investment in intangibles. ${ }^{22}$ To construct intangible investment for each firm, I follow the approach by Corrado et al. (2009) and include all investments in non-physical assets aimed at increasing the productivity of the firm. Intangible investment is the sum of four different accounting entries: R\&D expenditures, marketing and advertising, workers training and technology imports. The first two entries account for almost all intangible investment, and they both predict future productivity growth. ${ }^{23}$ It is important to consider intangible investments beyond R\&D also because many small or young firms find it too costly to complete R\&D paperwork, and instead may classify innovation-related expenditures as other intangible investments (e.g. marketing and advertising). ${ }^{24}$ Firms with zero reported $R \& D$ spending still declare significant amounts of product and process innovations.

It is certainly not the case that all categories of intangible investment generate positive spillovers to other firms. For example, marketing can have positive externalities when domestic firms enter in foreign markets and by doing so increase the demand for other domestic firms, but it can also involve capturing the demand for other firms. However, as previously discussed, as long as the fraction of private intangible capital which spills over to the pool of public intangible capital is positive and constant, the value of this fraction has no effect on the cyclical results of the model. Only relative changes over time in the stock of private intangible capital matter. Of course, the results do change if there are no spillovers at all (see Section 6).

I complement ESEE with data from the Public Registry of Firms, publicly available

\footnotetext{
${ }^{21}$ The employment share of firms with less than 10 employees is only 12 percent of the sector.

${ }^{22}$ Spanish accounting law (Royal Decree 1514/2007), which is in accordance with International Financial Reporting Standards, specifies that the book value of intangible assets is imputed at the cost of purchase or internal development of the asset, and depreciation is specific to the properties of each asset.

${ }^{23}$ With an earlier version of the same dataset, Doraszelski and Jaumandreu (2013) show that R\&D predicts productivity growth, and I find that one-year-lagged marketing and advertising rates are even more correlated with TFP growth than R\&D rates.

${ }^{24}$ Reporting $R \& D$ is particularly complicated due to the existence of $R \& D$ tax credits, which raise the bar for accounting standards.
} 
for recent years at the National Statistics Institute (INE) website. DIRCE has much less variables than ESEE, but it includes the whole population of manufacturing firms, which is helpful to compute firm representativity weights for ESEE and aggregate entry and exit rates.

Appendix A.3 provides a list of all the variables used for structural estimation, their summary statistics, and the bounds to winsorize outliers. After eliminating outliers, the remaining number of firm-year observations from 1992 to 2013 is 23,380. ${ }^{25}$ Each firm-year observation is weighted by its representativity. Firm representativity weights are constructed from DIRCE by sector of activity (20 categories in manufacturing) and employment size bin (1-19, 20-49, 50-99, 100-199 and 200+).

Before delving into the estimation method, it is informative to analyze the evolution of some key aggregate variables around the Great Recession. Figure 5 displays net debt issuances $\left(\frac{b^{\prime}-b}{k+a}\right)$ and total investment $\left(\frac{i_{k}+i_{a}}{k+a}\right)$ as a percentage of total assets for firms with lower and higher than average asset tangibility, before and after the Great Recession. Tangibility is defined as physical capital divided by total fixed assets $\left(\frac{k}{k+a}\right)$. Average tangibility is 57 percent, which leaves a 43 percent share of intangible assets in total fixed assets. We can see that intangible intensive firms were more affected by the recession: they drastically reduced their debt issuances and they cut total investment disproportionately more. Average leverage (debt over total assets) weighted by value added is 23 percent, so the observed change in debt issuances is economically significant. As we have seen in Figure 4, the fall in debt issuances coincided with an increase in the interest rates for debt and the equity premium, suggesting a fall in the supply of credit rather than in the demand. Figure 5 controls for firm size (fixed assets), age and sector of activity, and the pattern is robust to excluding non-exporters. The same relationship is observed across industries (Appendix A.4).

Figure 6 shows aggregate investment by all firms in the two types of capital separately $\left(\frac{i_{k}}{k+a}\right.$ and $\left.\frac{i_{a}}{k+a}\right)$. Both tangible and intangible investment have comparable magnitudes, and they both dropped after the Great Recession. This underscores the importance of including intangibles in business cycle models. ${ }^{26}$ Figure 7 shows that this pattern is shared by all the categories of intangible investment. Even though they have very different levels, they all feature a sharp decrease in the Great Recession. Consistent with the decline in intangible capital formation, aggregate total factor productivity (defined as value added net of labor and physical capital) fell by 5 percentual points between 2008 and 2013 in the ESEE sample. ${ }^{27}$

\footnotetext{
${ }^{25}$ The two years previous to 1992 are lost due to the lagged nature of some variables and lack of consistent definitions in 1990.

${ }^{26}$ Barlevy (2007) documents the procyclicality of R\&D in the U.S.

${ }^{27}$ Gopinath et al. (2017) obtain a slightly larger TFP fall with an overlapping sample of Spanish manufacturing firms from Amadeus and calibrating $\alpha+\beta=1 / 3$.
} 
Figure 5: Debt Issuances and Total Investment by Firm Tangibility
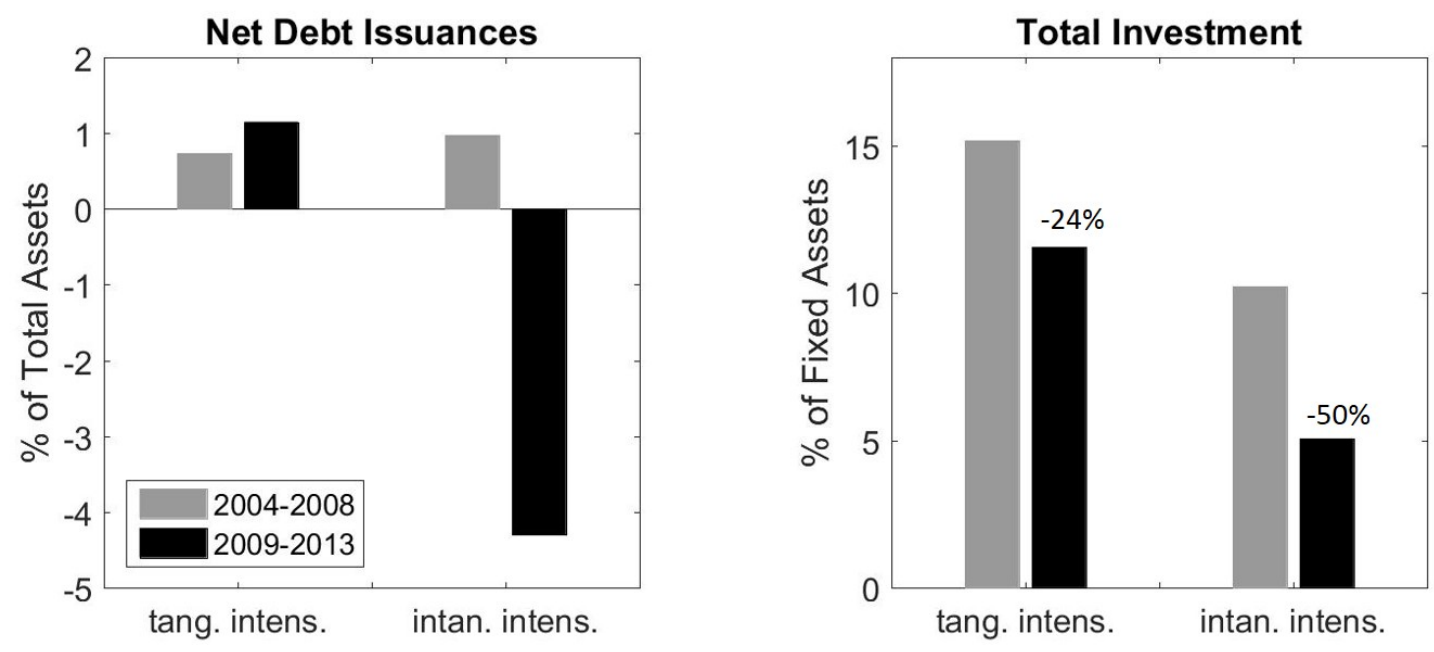

Notes: Sample: Spanish manufacturing firms. Source: ESEE. Tangibility = Tangible Assets / Total Fixed Assets. A firm is classified as tangible intensive if tangibility $>57$ percent.

That fall came on top of a prolonged slow decline since the late 1990s. A similar drop occurs in other measures of intangible outputs such as patents or reported product and process innovations.

Figure 6 also shows that tangible investment is more volatile. This fact is replicated by the quantitative model, as intangibles have a higher private depreciation rate and a higher adjustment cost (see estimated parameters in Table 2). These technological parameters prevent firms from disproportionately cutting intangible investment after an aggregate shock and transmit the adjustment to tangible investment.

Finally, Figure 8 shows the evolution of aggregate entry and exit rates. Since the onset of the Great recession, net entry rates (entry minus exit) experienced a persistent shift from positive (blue area) to negative (red area). ${ }^{28}$

\section{Estimation}

I use firm-level data to estimate the structural parameters of the model by the Simulated Method of Moments (SMM). In the model, heterogeneity across firms is caused by different current and past realizations of the idiosyncratic intangible depreciation shock $z$. I compare model-simulated and actual data for the same time period, feeding into the model the empirical history of aggregate shocks estimated in Section 4.1. The model is overidentified, so

\footnotetext{
${ }^{28}$ Indeed, Bentolila et al. (2013) document that the majority of job losses in Spain were due to firm closures rather than downsizing. Decker et al. (2017) report a similar qualitative pattern in U.S. entry and exit rates, although the U.S. rise in exit rates is not so persistent.
} 
Figure 6: Investment Rates

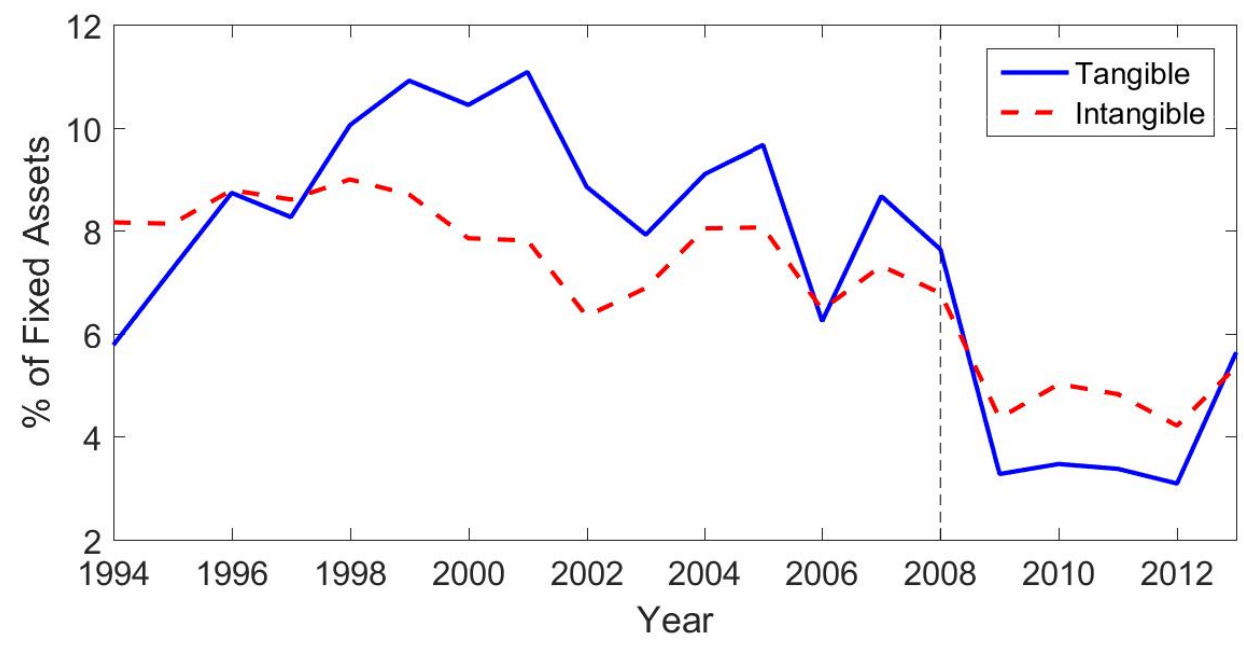

Notes: Sample: Spanish manufacturing firms. Source: ESEE.

Intangible investment $=\mathrm{R} \& \mathrm{D}+$ Marketing + Technology Imports + Workers Training.

Figure 7: Intangible Investment Decomposition
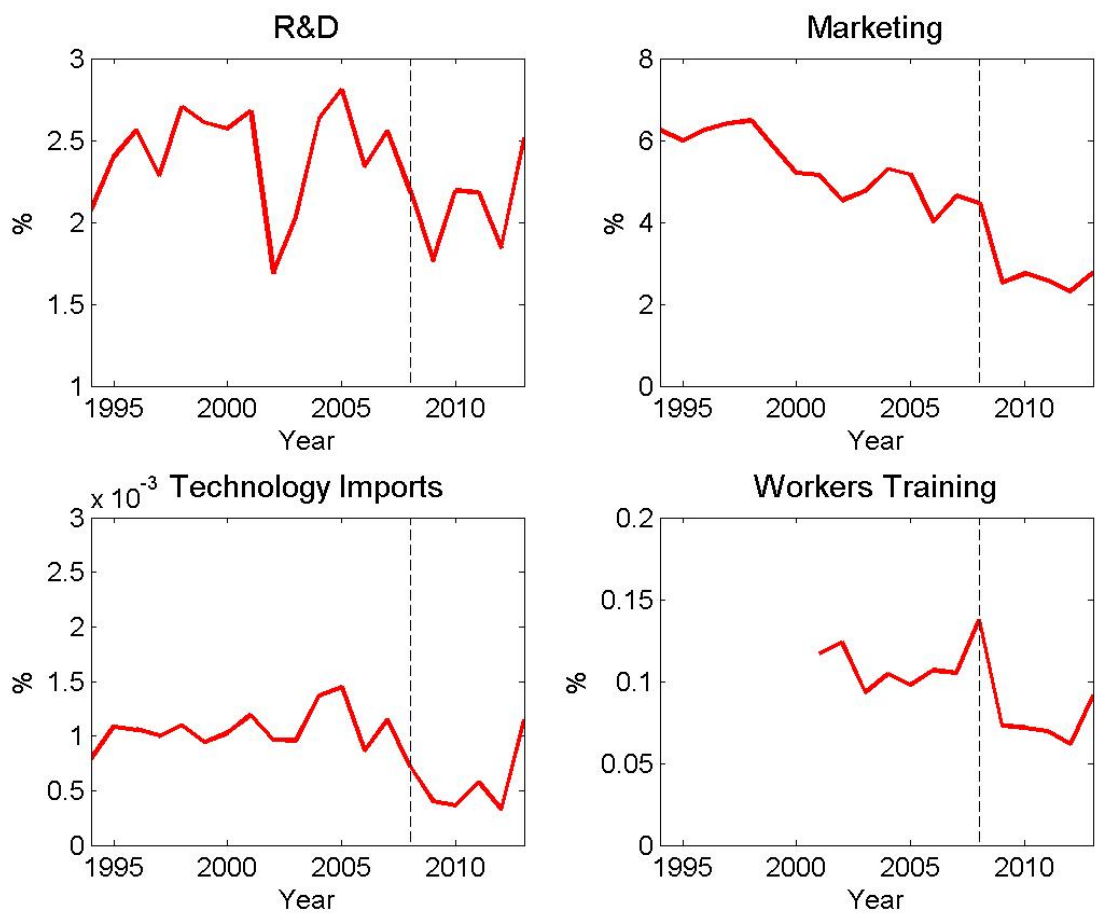

Notes: Sample: Spanish manufacturing firms. Source: ESEE. 
Figure 8: Entry and Exit Rates

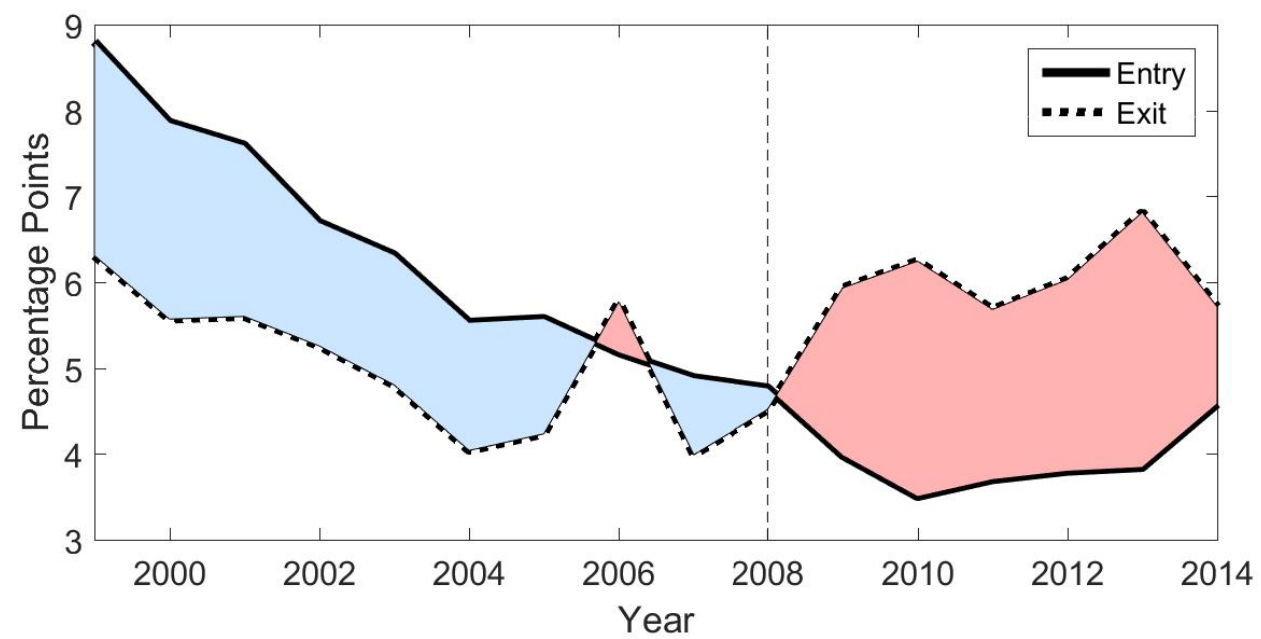

Notes: Sample: Spanish manufacturing firms. Source: Public Registry.

I minimize the squared distance in the moments weighted by the estimated optimal GMM matrix (see Appendix A.5 for details).

The estimation of the model only uses cross-sectional and within-firm moments. As an additional overidentifying check, Section 6 compares the model to the Spanish aggregate time series to assess the importance of the novel mechanisms.

\subsection{Identification and Results}

Table 2 lists the parameters in the model, their estimated values and standard errors, and the moments targeted for estimation. Since the model is overidentified, all the moments depend on multiple parameters. Yet, for intuition, in the table I align the parameters with the moment(s) that most directly identify each of them. Table 3 reports the comparison between data and simulated moments.

I proceed to discuss the intuition for the identification of the parameters. The exponents in the production function $\alpha$ and $\beta$ are identified respectively by the value-added-weighted average labor share and the average tangibility weighted by firm fixed assets. A larger $\alpha$ reduces the labor share and a larger $\beta$ reduces tangibility. Tangible and intangible capital have similar exponents (0.19), but intangibles depreciate faster, making their stock smaller in equilibrium. These results imply that the exponent on the public stock of intangibles $1-\alpha-\beta$, which governs the contribution of the spillover channel, is 0.62 , an arguably high value. Section 6 also considers the case where $A$ has constant growth, i.e., that there are no intangible capital spillovers. The depreciation rates of tangible and intangible capital $\delta_{k}$ and $\delta_{a}$ are estimated by matching the average investment rates of mature (older than 10 
Table 2: Firm-Level Parameters

\begin{tabular}{lcrrl}
\hline \hline parameter & label & value & s.e. & target(s) \\
\hline physical capital share & $\alpha$ & 0.19 & 0.02 & labor costs / value added \\
intangible share & $\beta$ & 0.19 & 0.01 & tangible / fixed assets \\
depreciation tangibles & $\delta_{k}$ & 0.08 & 0.02 & $\frac{i_{k}}{k}$ mature firms \\
depreciation intangibles & $\delta_{a}$ & 0.12 & 0.01 & $\frac{i_{a}}{a}$ mature firms \\
fixed cost & $T$ & 0.45 & 0.06 & average entry and exit rates \\
entry cost & $\gamma$ & -0.26 & 0.01 & average entry-exit gap \\
recovery creditor tang. & $\psi_{k}$ & 0.65 & 0.23 & leverage, slope $\left(\frac{i_{k}}{a+k}, \frac{b}{a+k}\right)$ \\
recovery creditor intan. & $\psi_{a}$ & 0.26 & 0.09 & leverage, slope $\left(\frac{i_{a}}{a+k}, \frac{b}{a+k}\right)$ \\
adjust. cost tangibles & $\eta_{k}$ & 0.08 & 0.02 & within std. dev. $\frac{i_{k}}{a+k}$ \\
adjust. cost intangibles & $\eta_{a}$ & 0.18 & 0.10 & within std. dev. $\frac{i_{a}}{a+k}$ \\
autocorrelation shock & $\rho$ & 0.09 & 0.03 & autocorrelation $\frac{i_{a}}{a+k}$ \\
std. dev. shock & $\theta$ & 0.85 & 0.16 & correlation $\left(\frac{i_{a}}{a}, \frac{\Delta a}{a}\right)$ \\
entrants net debt & $b_{0}$ & -1.49 & 0.38 & relative employment entrants \\
elasticity of subs. varieties & $\sigma$ & 4 & - & calibrated \\
\hline
\end{tabular}

Notes: See Appendix A.5 for the computation of standard errors.

years) firms, which tend to invest as much as needed to replace their depreciated capital stock, weighted by tangible and intangible assets respectively. The private depreciation rate of intangibles is larger (12 vs 8 percent for tangibles), consistent with the results in Corrado et al. (2012). The fixed production cost $T$ is expressed as a fraction of the frictionless steadystate operating profits $(p y-W l$ ) of a firm with constant $z=1$, and is estimated to 45 percent to match the average annual entry and exit rates, which are increasing in $T$. Actual entry and exit rates fluctuate over time according to the history of realizations of the aggregate state. The entry cost $\gamma$ is identified by the average absolute gap between entry and exit rates. Higher values of $\gamma$ increase the threshold for entry. The entry cost $\gamma$ is estimated to be 26 percent of the initial debt of entrants $b_{0}$.

The parameters which directly relate to the financial constraints in my model are the fractions that debtholders can recover from each type of asset in case of firm default, $\psi_{k}$ and $\psi_{a}$, and the adjustment cost parameters, $\eta_{k}$ and $\eta_{a}$, which determine how much value is lost after liquidation. The estimated creditor recovery rates are 65 percent of the tangible assets left after liquidation and only 26 percent of the intangibles. ${ }^{29}$ The remaining fractions are captured by owners. The recovery rates are identified by the value-added-weighted average leverage ratios (outstanding debt over total assets) and the slope coefficient of tangible

\footnotetext{
${ }^{29}$ Altman and Kishore (1996) report that the percentage of the face value of corporate bonds (not of a firm's assets) that is recovered by bondholders in case of default ranges from 30 to 70 percent across industries. Regarding the difference between asset types, the lack of collateralizability of intangibles is consistent with the evidence in Falato et al. (2013), who show empirically that firms with more tangibility also have higher levels of leverage, whereas firms with more intangibles preferentially use internal financing.
} 
and intangible investment rates with respect to the firm's current leverage. Higher observed leverage ratios indicate that firms' ability to commit is larger, and so will lead to the inference that recovery rates for creditors are higher. Targeting average leverage of productive firms is particularly important when analyzing financial frictions, and is a step above most of the quantitative macrofinance literature, which often targets financial intermediaries leverage instead, implying unrealistically high leverage ratios for the representative producer (see Shourideh and Zetlin-Jones (2017) for a discussion). To distinguish the recovery rates for the two types of assets, I look at the slope coefficient of the two types of investment on leverage. The slope coefficient of tangible and intangible investment rates is obtained from a regression of these two variables on all the states of the firm which are observable in the data: the log of fixed assets, tangibility, leverage, firm's age, sector of activity and year fixed effects; weighted by firm total assets. Lower recovery rates for each type of asset make the respective investment rate more sensitive to debt. The adjustment costs are such that upon liquidation firms lose 8 percent of the value of tangible assets and 18 percent of the value of intangibles, reflecting the fact that intangible capital is more firm-specific. These are identified by the within-firm volatility of positive investment rates in the two types of capital, which is decreasing in adjustment costs. ${ }^{30}$

The parameters that govern the idiosyncratic shock process $z$ are its autocorrelation $\rho$ and the standard deviation $\theta$ of its error term. I identify the autocorrelation of the depreciation shock by targeting the autocorrelation of the intangible investment rate (weighted by firm total assets). The standard deviation is identified by the correlation between intangible investment rates and the evolution of the stock of intangibles, as a difference from the same statistic for tangible capital. Since the shock $z$, which is observed after the firms decision to invest, determines the relationship between intangible investment expenditure and formation of intangible capital, the more volatile is $z$ the weaker the correlation will be.

Finally, the exogenous initial (negative) debt of entrants $b_{0}$, expressed as a fraction of frictionless steady-state operating profits of a firm with constant $z=1$, is set to match the life-cycle growth in employment by firm age (age $\leq 5$ vs age $>5$ ). Due to investment adjustment costs and financial frictions, it takes time for entrants to accumulate the "mature" optimal level of tangible and intangible capital if they start with few initial internal resources.

The only parameter I cannot estimate is the elasticity of substitution across varieties $\sigma$, as I do not have data on firm total costs to compute markups, so I use the estimate from Broda and Weinstein (2006) for three-digit categories of US imports.

\footnotetext{
${ }^{30}$ I only look at positive values because sales of intangible assets (which are infrequent) are not reported in the ESEE survey.
} 
Table 3: Moments Fit

\begin{tabular}{lrrr}
\hline \hline moment & data & s.e. & model \\
\hline labor costs / value added & 60.9 & 1.7 & 61.1 \\
tangible / fixed assets & 55.6 & 5.3 & 51.6 \\
average $\frac{i_{k}}{k}$ mature firms & 11.9 & 0.6 & 11.7 \\
average $\frac{i_{a}}{a}$ mature firms & 15.6 & 4.1 & 16.2 \\
average entry and exit rates & 5.4 & 0.6 & 5.3 \\
average entry-exit gap & 1.7 & 1.1 & 1.2 \\
within std. dev. $\frac{i_{k}}{a+k}$ & 20.0 & 0.4 & 5.7 \\
within std. dev. $\frac{i_{a}}{a+k}$ & 11.4 & 0.5 & 3.1 \\
correlation $\left(\frac{i_{a}}{a}, \frac{\Delta a}{a}\right)$ & 29.0 & 4.4 & 18.6 \\
relative employment entrants & 64.0 & 3.7 & 65.5 \\
slope coeff. $\frac{i_{k}}{a+k}$ on $\frac{b}{a+k} *$ & -0.05 & 0.01 & -0.02 \\
slope coeff. $\frac{i_{a}}{a+k}$ on $\frac{b}{a+k} *$ & -0.10 & 0.02 & -0.02 \\
autocorrelation $\frac{i_{a}}{a+k}$ & 56.2 & 9.6 & 49.8 \\
average leverage & 18.3 & 0.7 & 22.8 \\
\hline
\end{tabular}

Notes: Asterisks $\left(^{*}\right)$ refer to coefficients from a regression of $\frac{i_{x}}{a+k}$ on log assets, tangibility, leverage, age, sector of activity and year fixed effects, where $x=\{k, a\}$.

\subsection{Goodness of Fit}

Table 3 contains the values of all the moments targeted, in the data and in the model simulation, as well as the moment standard errors in the data. We can see that the fit of the model is accurate with respect to the majority of moments, but not all of them, as the estimation is overidentified. In particular, the model has trouble in fitting the high within-firm volatility in the data. Lower adjustment costs or a higher standard deviation of the idiosyncratic shock would help in this dimension, but they would generate an excessive average leverage ratio. However, investment volatility in the data is likely to be exaggerated by measurement error. Relatedly, average value-added-weighted leverage is a bit too high in the model, as firm size is more disperse in the data and very large firms tend to have lower leverage ratios. Appendix A.4 shows the fit for the entire leverage distribution.

\section{Macroeconomic Analysis}

Once the model is estimated, it can be used to examine the role of endogenous intangible investment in explaining the extent and the components of the "Great Deviation" that followed the Great Recession. 
Figure 9: Aggregate Value Added vs Data
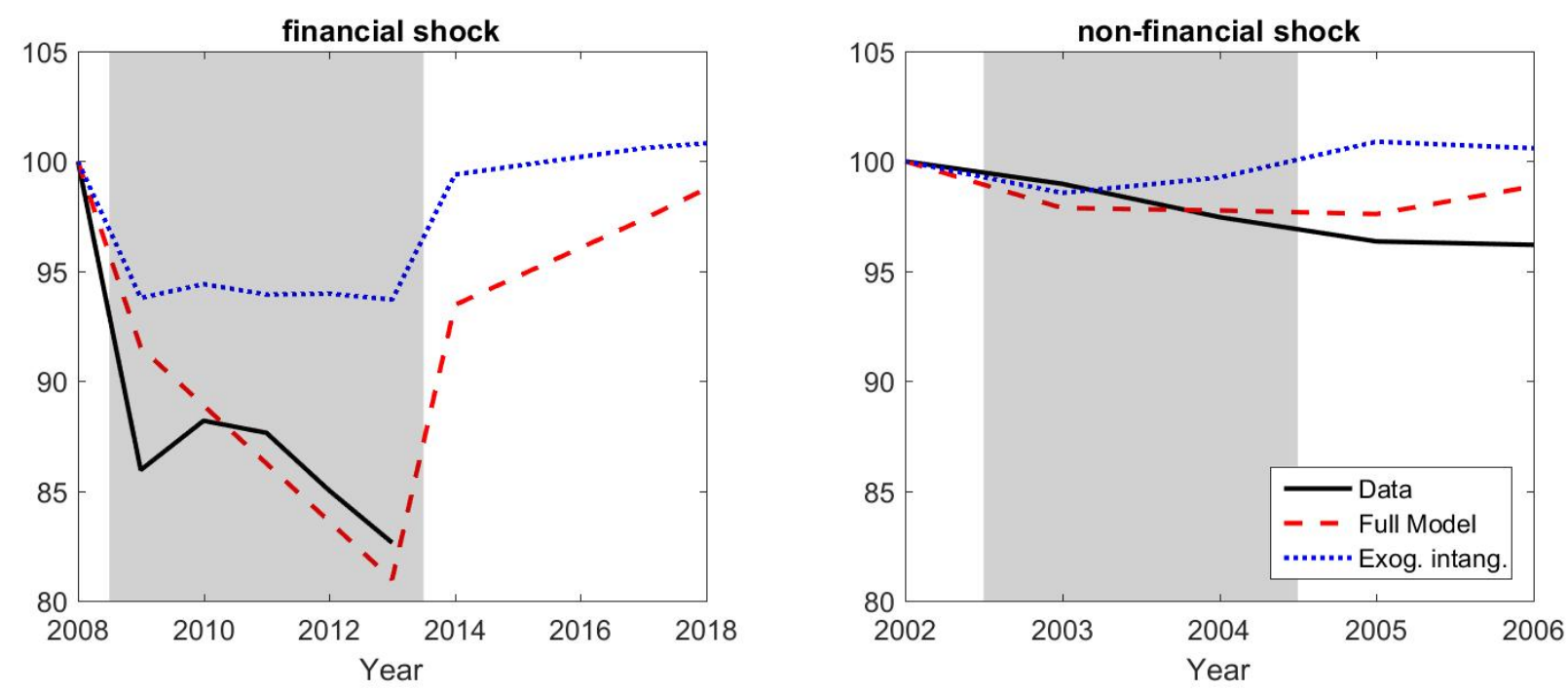

Notes: Deviations with respect to the log-linear trend. Estimated aggregate states: financial shock in 2009-13, non-financial shock in 2003-04, normal otherwise. Sample: Spanish manufacturing firms. Source: INE.

\subsection{The Great Deviation}

Figure 9 compares the evolution of Spanish manufacturing GDP (aggregate value added) in the data and in the model. The figure also shows results for a standard model with exogenous intangible investment, but with the same idiosyncratic and aggregate shocks (see details in Appendix A.2). The standard model lacks the effect of higher financing costs for intangible investment and the intangible spillovers. I feed into the two models the series of European aggregate shocks estimated in Section 4.1. The periods plotted capture a financial shock (2009-2013) and a non-financial shock (2003-2004), marked with shaded areas, both followed by a return to the normal state (by assumption for the post-2013 period).

Starting with the financial shock, the full model is able to fit the extent of the GDP fall between 2008 and 2013, and it predicts a persistent deviation from trend (even under the assumed best-case scenario of an immediate return to the normal state in 2014). In contrast, the standard model misses more than half of the GDP fall in the Great Recession and generates a quick rebound to trend (which is the baseline in a frictionless open-economy model). In the case of the non-financial shock, which is much smaller in size, the two models evolve more similarly. ${ }^{31}$

\footnotetext{
${ }^{31}$ The reaction to a non-financial shock is still larger for the full model, as the additional stock of capital with more severe borrowing frictions and spillovers amplifies any kind of shock. Yet, financial shocks generate a much larger gap across models.
} 
Table 4: GDP Change Decomposition

\begin{tabular}{lrrrrrr}
\hline \hline & \multicolumn{2}{c}{ full model } & \multicolumn{1}{c}{ exog. intan. } & no spillov. & same $\psi$ \\
\hline & $2008-13$ & $2008-18$ & $2008-13$ & $2008-18$ & $2008-13$ & $2008-13$ \\
\hline global income & -1.9 & 0 & -1.9 & 0 & -1.9 & -1.9 \\
physical capital & -2.0 & -0.1 & 0.2 & 0.3 & -1.7 & -0.2 \\
private intan. capt. & -1.6 & -0.3 & -0.2 & 0.0 & -1.7 & -0.4 \\
public intan. capt. & -0.1 & -0.1 & 0 & 0 & 0 & 0.0 \\
labor & -11.4 & -0.8 & -3.8 & 0.5 & -11.0 & -4.6 \\
allocative efficiency & -2.0 & -0.1 & -0.5 & 0.1 & -2.0 & -0.5 \\
\hline entrants & -6.8 & 3.5 & -0.8 & 0.0 & -5.8 & 1.4 \\
incumbents & -7.8 & -0.6 & -5.1 & 1.0 & -9.1 & -6.8 \\
exiters & -4.5 & -4.1 & -0.5 & -0.2 & -3.1 & -2.1 \\
\hline total & $\mathbf{- 1 9 . 0}$ & $\mathbf{- 1 . 2}$ & $\mathbf{- 6 . 3}$ & $\mathbf{0 . 8}$ & $\mathbf{- 1 8 . 0}$ & $\mathbf{- 7 . 5}$ \\
\hline
\end{tabular}

Notes: Percentual contributions to the deviation in GDP with respect to trend. "exog. intan." refers to a model without endogenous intangible investment (details in Appendix A.2), "no spillov." to a model without spillovers $(A=1)$, and "same $\psi "$ to a model where intangibles are as collateralizable as tangibles.

\subsection{Components}

To shed light on the reasons behind the discrepancy between models, Table 4 decomposes the GDP change with respect to trend for the periods 2008-13 and 2008-18. This allows us to distinguish between channels of amplification (while the economy is hit by a financial shock) and persistence (after the aggregate state goes back to normal). The table presents the decomposition by production factors and into entrants, incumbents and exiters. It includes results for the full model with all the channels and for the standard model with exogenous intangible investment. To identify the individual structural factors causing amplification, the table also presents results for a model without intangible capital spillovers $(A=1)$ and for a model where intangible assets are as collateralizable as tangible assets $\left(\psi_{h}=\psi_{k}=0.65\right)$.

Let us start analyzing the decomposition by production factors. GDP, which is defined as aggregate value added by domestic firms, can be decomposed as follows:

$$
\sum_{j=1}^{N} p^{j} y^{j}=D^{\frac{1}{\sigma}} E\left(A^{1-\alpha-\beta} a^{\beta} k^{\alpha} l^{1-\alpha}\right)^{\frac{\sigma-1}{\sigma}} .
$$

Here, all variables without the superscript $j$ denote aggregates. For example, $a$ is the sum of private intangible capital in the economy. Time subscripts are omitted. The variable $E$ denotes allocative efficiency and is obtained as a residual, as in the Olley-Pakes decomposition (Olley and Pakes (1996)).

The first row in Table 4 gives the contribution of the exogenous global income shock $D$, i.e., the change in GDP if domestic producers did not react to the aggregate shock. Obviously, 
this is the same for all models. Across the table rows, labor is the variable that accounts for the largest GDP changes. This is not surprising due to the presence of one-period labor contracts in the model, the magnitude of the labor share and wage rigidity. Comparing the first two columns, we can see that the stock of intangible capital has more persistent dynamics (recovers more slowly) than physical capital. Although public intangible capital has a limited contribution, it is the most persistent component, as its fall is larger for the whole decade than for the crisis period. It keeps destroying GDP even when the aggregate state goes back to normal. Since the model features firm heterogeneity and frictions to reallocate capital across firms after shocks, allocative efficiency substantially worsens in the Great Recession. In this model, measured TFP in revenues is equal to aggregate GDP divided by the contribution of physical capital and labor: $\left(k^{\alpha} l^{1-\alpha}\right)^{\frac{\sigma-1}{\sigma}}$. The measured TFP fall between 2008-13 is 5.6 percent in the model and 5.0 percent in the ESEE data. More generally, the endogenous response of TFP suggests that financial shocks may explain a larger fraction of the business cycle than obtained by previous decompositions with exogenous TFP shocks (Jermann and Quadrini (2012)).

In the exogenous intangible investment model (columns three and four), the response in the private and public intangible stocks is muted. Due to complementarities in the production function, this also leads to a lower contribution from labor and physical capital compared to the full model. ${ }^{32}$ Adding up all channels, the model with endogenous intangible investment predicts an additional 12.7 percentual points of GDP fall between 2008-2013, and still a persistent difference of 2 points by 2018.

The causal contribution of spillovers can be gauged by comparing columns one and five, which presents the decomposition results for a model where public intangible capital is kept constant relative to the trend. Spillovers amplify all channels as they propagate movements in intangible investment over time, but their total effect is modest, adding one percentage point to the 2008-13 GDP fall. Finally, assuming that intangibles are as collateralizable as tangibles eliminates a great chunk of the Great Depression and brings us close to the standard model (column six). Hence, financial constraints seem to be the primary cause of amplification. Indeed, in countries with deeper private and public equity markets, such as the U.S., the fall in both GDP and TFP after the Great Recession has been shallower and much less persistent than in most European countries (see Fernald (2012) and Hall (2016)), which rely more heavily on bank loans.

To decompose into entrants, incumbents and exiters, I compute the difference between the contribution of each group and the average contribution on the BGP. It is necessary to

\footnotetext{
${ }^{32}$ The compositional effect of entry and exit generates the positive response in physical capital and the non-zero movement in private intangible capital.
} 
establish this relative measure because, by definition, in any period entrants create value added and exiters destroy it. The first observation is that all groups contribute less than normal in the Great Recession. The bulk of the changes when the financial shock hits is due to incumbents, but exiters seem to generate more persistence. This is because it takes some time for the balance sheet position of a firm to deteriorate and induce liquidation. Comparing to the exogenous-intangible-investment model, exiters are the group that accounts for larger differences in the whole decade.

\subsection{Policy}

The policy debate in Europe is dominated by the need to speed up the recovery after the Great Recession. The European Commission has implemented the European Investment Plan, also known as the Juncker Plan, which is a program of subsidized credit to risky investments, with a stated goal to relieve credit constraints. This section proposes alternative policies which, according to the model, could help better achieve this goal, moving the economy closer to the first best at no public cost. ${ }^{33}$

In the model, expected welfare is proportional to the sum of existing firm value, since all agents own a perfectly diversified portfolio. Hence, the first best implies equalizing the marginal product of physical capital and the marginal product of intangible capital across firms. However, the decentralized equilibrium is inefficient due to the presence of financial frictions, in the form of the no-equity issuance constraint and limited commitment, and intangible capital spillovers. Any policy that increases the investment rate of the firms with higher marginal returns to investment will increase efficiency. Here I consider schemes of transfers conditional on firm observable characteristics that correlate with investment returns: age and size.

Let us first analyze age-based transfers. Transferring equity to younger firms relaxes the borrowing constraint of the firms with a higher marginal product of tangible and (especially) intangible capital. ${ }^{34}$ To avoid concerns about manipulation of firm age, I restrict the analysis to a one-time unanticipated transfer. I compute the optimal set of transfers by age in 2009, conditional on the transfers being budget neutral, i.e. summing up to zero across firms. The optimal policy is the one maximizing the sum of incumbent firm value in the Spanish manufacturing sector in 2009. For tractability, I search for the optimum within the class of transfer schemes proportional to the average firm net debt interest rate $\left(q_{b}\right)^{-1}-1$ by age.

\footnotetext{
${ }^{33}$ The analysis abstracts from administrative costs of policy implementation.

${ }^{34}$ Dyrda (2016) shows how firm age may matter for financial constraints in the presence of long-term financial contracts. Here, the relevance of firm age is due to the combination of low initial equity levels and investment adjustment costs.
} 
Figure 10: Optimal Transfer by Age in 2009

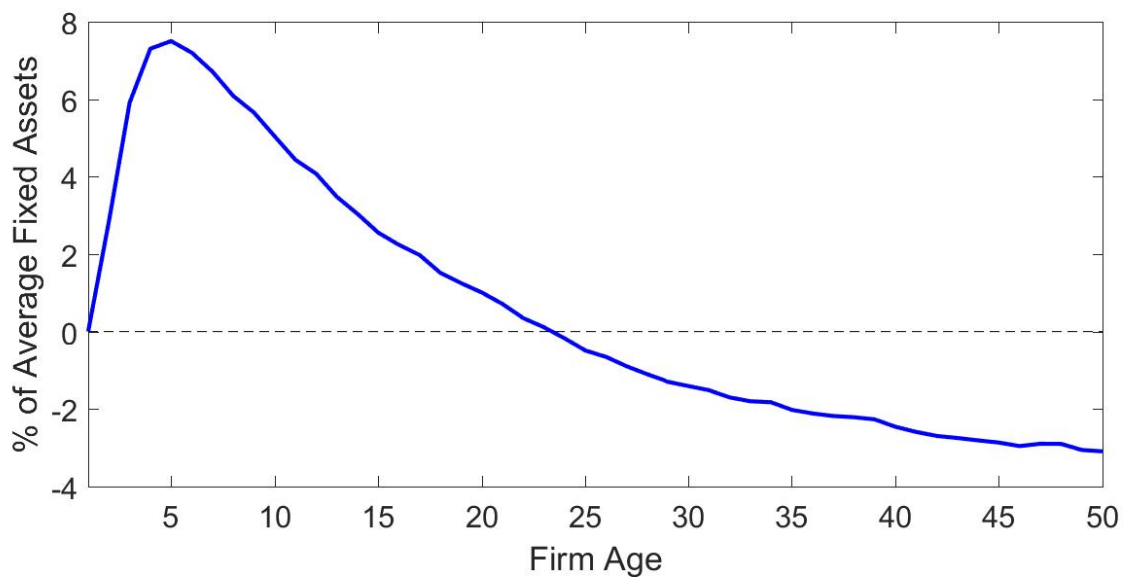

By firm optimality, the interest rate is approximately equal to the expected marginal private return to tangible and intangible investment. ${ }^{35}$ Hence, the sum of firm value tends to be maximized if resources are reallocated towards firms with higher interest rates in equilibrium. Such a reallocation boosts aggregate investment and reduces inefficient firm exit.

Figure 10 plots the optimal transfer by age as a percentage of average firm fixed assets. The transfer is positive for young firms, which are more financially constrained, and negative for older firms. Notably, for very young firms, the transfer is increasing in age. This is because with investment adjustment costs entrants take some time to accumulate leverage, and so the most financially constrained firms are those between 4 and 8 years of age. Figure 11 shows the effects of the policy on aggregate GDP. Even if this is a one-time policy, it generates a persistent increase in GDP with respect to the no-policy benchmark. It avoids 3.3 percentual points of the 2008-2013 fall (17 percent of the total fall) and brings the economy back to the trend faster. The benefits of the policy accrue gradually as financially constrained firms progressively reduce their leverage, increase investment and avoid exit compared to the nopolicy baseline, whereas a few old firms are forced to exit in 2009.

Figure 11 also shows results for a policy targeting firms based on their size (employment), instead of their age. I follow the same procedure as for age-based transfers and compute the optimal one-time unanticipated budget-neutral scheme of transfers proportional to labor $l$ in 2009. ${ }^{36}$ Compared to conditioning on age, size is less correlated with a firm's marginal return. Firms which are small not because they are young, but because they have suffered negative idiosyncratic shocks, do not have higher marginal returns. On the other hand, targeting transfers to small firms helps reduce inefficient exit even further, as small firms

\footnotetext{
${ }^{35}$ It is not exactly equal because the bond price $q_{b}$ is a function of current tangible and intangible investment, so the marginal cost of debt includes the decrease in the bond price as a firm invests more.

${ }^{36}$ Firms are allowed to readjust their labor choice in the period when the policy transfers take place.
} 
Figure 11: Effect of the Optimal Transfers on GDP

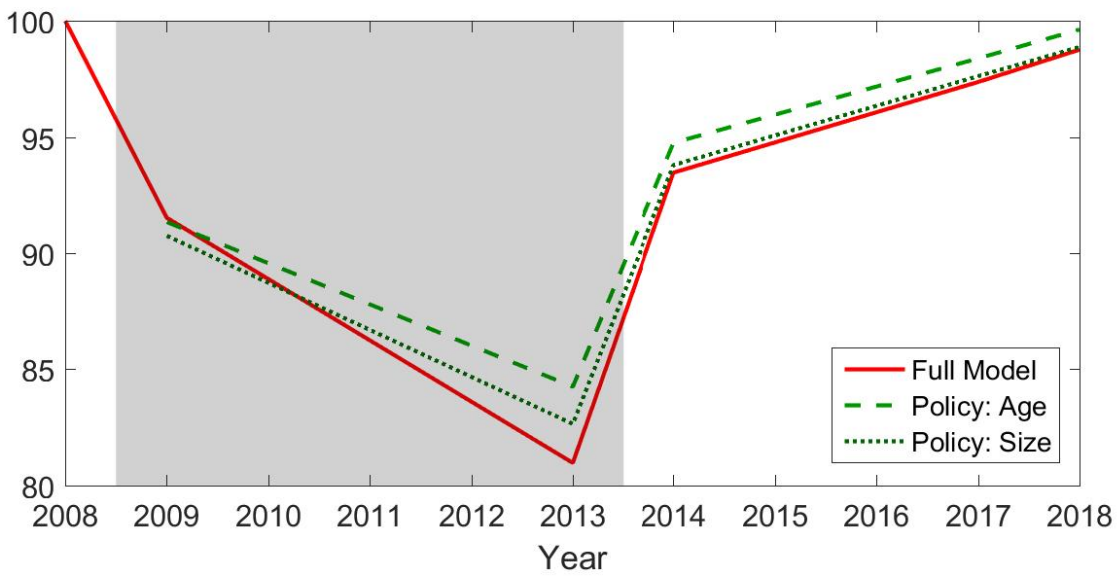

Notes: Aggregate states: financial shock in 2009-13, normal otherwise.

are proportionally more affected by the fixed production cost. Numerically, I find that conditioning on firm size is slightly less effective than conditioning on age, as the optimal scheme only avoids 1.7 percentual points of the 2008-2013 GDP drop.

My analysis tries to stay within the realm of implementable macro policies. Basing the policy on firm age or employment avoids the need for the government to collect information about harder to observe and contract upon variables such as corporate loan interest rates, leverage, assets or tangible and intangible investments. An indicator that these costs are relevant in practice is the fact that many young and/or small firms do not report any R\&D expenditures in spite of the presence of tax credits to R\&D in many OECD countries, including Spain. The age-based policy could be implemented via corporate income or social security tax credits conditional on the age of the firm's oldest plant, but operational challenges remain. The one-time unanticipated nature of the policy in the model avoids manipulation of firm age such as firms changing their name or their establishment location to appear younger. ${ }^{37}$ However, this type of analysis has the obvious caveat that the policy schemes are not time consistent. Anticipation of the policy could lead to an even larger increase in investment rates, which would be desirable, but also to inefficient firm entry, spinoffs or to the creation of screen companies with the purpose of cashing in the transfer.

In a framework with heterogeneous firms and endogenous borrowing constraints, a policy of credit subsidies (such as the Juncker Plan) is dominated by well-targeted outright transfers. Lowering the interest rates paid by firms by a moderate amount increases their capacity to leverage only marginally, through the positive income effect on net worth, but the incentives to default are barely changed. Therefore, government-subsidized credit crowds out most of

\footnotetext{
${ }^{37}$ Even if the policy is anticipated by some months, the result in Figure 10 that the optimal transfer is close to zero for one-year-old firms means that firm entry in response to the policy does not yield fiscal gains.
} 
private unsubsidized credit. On the contrary, if the discount on interest rates is too large, the policy can also distort the investment decisions of unconstrained firms by inducing them to leverage in excess.

In any case, it is important to note that targeted policies can only be second-best, as the correlation of the marginal returns to investment with easily-observable firm characteristics is not perfect. Microeconomic legal reforms aimed at increasing pledgeability of assets or at facilitating the development of external equity financing channels would be first-best.

\section{Conclusions}

Standard macroeconomic models of financial frictions have difficulties generating large real effects after financial shocks and cannot explain qualitatively why financial recessions last longer. In this paper I show that modeling the properties of intangible assets generates additional channels for amplification and persistence in response to an increase in the price of aggregate risk. Intangible assets are less collateralizable, take longer to recover after firm exit, and have lower social depreciation rates due to their spillovers to other firms. These properties imply that financing costs for intangible investment are disproportionately sensitive to financial conditions and that shocks to intangibles have more persistent effects.

I estimate the model structurally with data on Spanish manufacturing firms and compare the simulated data with the aggregate macro time series in Spain. Endogenous intangible investment can explain the extent and the components of the fall in output after the Great Recession. As in the data, lower intangible investment and increased exit rates are two important channels for amplification.

My model also provides a framework to predict the short and medium-run effects of firm fiscal policy. In particular, transferring funds to younger firms could be a more efficient policy than targeting small firms or subsidizing credit.

Avenues for future research include studying the frictions related to public and private equity issuances for firms investing in intangibles, as well as allowing for imperfect portfolio diversification by firm owners, longer lags in the formation of intangible capital, and differentiated parameters for each type of intangible capital. Regarding the empirical part, the analysis in this paper would benefit from linking data on firm-level debt interest rates to measures of intangible investment and asset tangibility. That would enable a more direct identification of the parameters determining financial constraints. More broadly, an explicit consideration of the cyclical changes in the price of aggregate risk observed in the data should be in the agenda of future work on the real effects of financial crises. 


\section{References}

Acemoglu, D., Akcigit, U., Bloom, N., and Kerr, W. R. (2013). Innovation, Reallocation and Growth. NBER Working Paper 18993.

Aghion, P., Angeletos, G.-M., Banerjee, A., and Manova, K. (2010). Volatility and Growth: Credit Constraints and the Composition of Investment. Journal of Monetary Economics, $57(3): 246-265$.

Aghion, P., Askenazy, P., Berman, N., Cette, G., and Eymard, L. (2012). Credit Constraints and the Cyclicality of R\&D Investment: Evidence from France. Journal of the European Economic Association, 10(5):1001-1024.

Altman, E. I. and Kishore, V. M. (1996). Almost Everything You Wanted to Know about Recoveries on Defaulted Bonds. Financial Analysts Journal, 52(6):57-64.

Anzoategui, D., Comin, D., Gertler, M., and Martinez, J. (2017). Endogenous Technology Adoption and R\&D as Sources of Business Cycle Persistence. Mimeo, New York University.

Ates, S. T. and Saffie, F. E. (2016). Fewer but Better: Sudden Stops, Firm Entry, and Financial Selection. PIER Working Paper 14-043.

Barlevy, G. (2007). On the Cyclicality of Research and Development. American Economic Review, 97(4):1131-1164.

Benigno, G. and Fornaro, L. (2015). Stagnation Traps. Mimeo.

Benmelech, E. and Bergman, N. K. (2009). Collateral Pricing. Journal of Financial Economics, 91(3):339-360.

Bentolila, S., Jansen, M., Jiménez, G., and Ruano, S. (2013). When Credit Dries Up: Job Losses in the Great Recession. CEPR Discussion Paper No. DP9776.

Bernanke, B. and Gertler, M. (1989). Agency Costs, Net Worth, and Business Fluctuations. American Economic Review, 79(1):14-31.

Bernanke, B. S., Gertler, M., and Gilchrist, S. (1999). The Financial Accelerator in a Quantitative Business Cycle Framework. Handbook of Macroeconomics, 1:1341-1393.

Bianchi, F. and Kung, H. (2014). Growth, Slowdowns, and Recoveries. NBER Working Paper 20725. 
Bloom, N., Schankerman, M., and Van Reenen, J. (2013). Identifying Technology Spillovers and Product Market Rivalry. Econometrica, 81(4):1347-1393.

Broda, C. and Weinstein, D. E. (2006). Globalization and the Gains From Variety. The Quarterly Journal of Economics, 121(2):541-585.

Buera, F. J., Kaboski, J. P., and Shin, Y. (2011). Finance and Development: A Tale of Two Sectors. American Economic Review, 101(5):1964-2002.

Buera, F. J. and Moll, B. (2015). Aggregate Implications of a Credit Crunch: The Importance of Heterogeneity. American Economic Journal: Macroeconomics, 7(3):1-42.

Catherine, S., Chaney, T., Huang, Z., Sraer, D. A., and Thesmar, D. (2017). Aggregate Effects of Collateral Constraints. Mimeo.

Cochrane, J. H. (1999). New Facts in Finance. NBER Working Paper 7169.

Comin, D. and Gertler, M. (2006). Medium-Term Business Cycles. American Economic Review, 96(3):523-551.

Corrado, C., Haskel, J., Jona-Lasinio, C., and Iommi, M. (2012). Intangible Capital and Growth in Advanced Economies: Measurement Methods and Comparative Results. Available at http://www.intan-invest.net.

Corrado, C., Hulten, C., and Sichel, D. (2009). Intangible Capital and US Economic Growth. Review of Income and Wealth, 55(3):661-685.

De Ridder, M. (2016). Investment in Productivity and the Long-Run Effect of Financial Crises on Output. Cambridge INET Working Paper Series No: 2016/18.

Decker, R., Haltiwanger, J., Jarmin, R. S., and Miranda, J. (2017). The Secular Decline in Business Dynamism in the US. FEDS Working Paper 2017-019.

Doraszelski, U. and Jaumandreu, J. (2013). R\&D and Productivity: Estimating Endogenous Productivity. The Review of Economic Studies, 80(4):1338-1383.

Duval, R. A., Hong, G. H., and Timmer, Y. (2017). Financial Frictions and the Great Productivity Slowdown. IMF Working Paper No. 17/129.

Dyrda, S. (2016). Fluctuations in Uncertainty, Efficient Borrowing Constraints and Firm Dynamics. Mimeo. 
Eisfeldt, A. L. and Papanikolaou, D. (2013). Organization Capital and the Cross-Section of Expected Returns. The Journal of Finance, 68(4):1365-1406.

Falato, A., Dalida, K., and Sim, J. W. (2013). Rising Intangible Capital, Shrinking Debt Capacity, and the US Corporate Savings Glut. No. 2013-67. Board of Governors of the Federal Reserve System (US).

Fariñas, J. C. and Jaumandreu, J. (1995). La Encuesta sobre Estrategias Empresariales: Características y Usos. Fundación Empresa Pública.

Fernald, J. G. (2012). Productivity and Potential Output Before, During, and After the Great Recession. Federal Reserve Bank of San Francisco Working Paper 2012-18.

Garga, V. and Singh, S. R. (2016). Output Hysteresis and Optimal Monetary Policy. Mimeo.

Gertler, M. and Karadi, P. (2011). A Model of Unconventional Monetary Policy. Journal of Monetary Economics, 58(1):17-34.

Gertler, M. and Kiyotaki, N. (2013). Banking, Liquidity and Bank Runs in an InfiniteHorizon Economy. NBER Working Paper 19129.

Gilchrist, S., Sim, J. W., and Zakrajšek, E. (2013). Misallocation and Financial Market Frictions: Some Direct Evidence from the Dispersion in Borrowing Costs. Review of Economic Dynamics, 16(1):159-176.

Gilchrist, S. and Zakrajšek, E. (2012). Credit Spreads and Business Cycle Fluctuations. American Economic Review, 102(4):1692-1720.

Gomes, J. F. and Schmid, L. (2010). Equilibrium Credit Spreads and the Macroeconomy. The Wharton School Research Paper, (42).

Gopinath, G., Kalemli-Ozcan, S., Karabarbounis, L., and Villegas-Sanchez, C. (2017). Capital Allocation and Productivity in South Europe. Quarterly Journal of Economics, forthcoming.

Gourieroux, C. and Monfort, A. (1997). Simulation-Based Econometric Methods. Oxford University Press.

Gourio, F. (2012). Disaster Risk and Business Cycles. American Economic Review, 102(6):2734-2766.

Guerrón-Quintana, P. and Jinnai, R. (2015). Liquidity, Trends and the Great Recession. Tokyo Center for Economic Research Paper No. E-66. 
Hall, R. E. (2016). Macroeconomics of Persistent Slumps. Handbook of Macroeconomics, $2: 2131-2181$.

Hennessy, C. A. and Whited, T. M. (2007). How Costly is External Financing? Evidence from a Structural Estimation. The Journal of Finance, 62(4):1705-1745.

Jermann, U. and Quadrini, V. (2012). Macroeconomic Effects of Financial Shocks. American Economic Review, 102(1):238.

Jorda, O., Schularick, M., and Taylor, A. M. (2013). When Credit Bites Back. Journal of Money, Credit and Banking, 45(s2):3-28.

Khan, A., Senga, T., and Thomas, J. K. (2014). Default Risk and Aggregate Fluctuations in an Economy with Production Heterogeneity. Ohio State University working paper.

Khan, A. and Thomas, J. K. (2013). Credit Shocks and Aggregate Fluctuations in an Economy with Production Heterogeneity. Journal of Political Economy, 121(6):10551107.

King, R. G. and Levine, R. (1993). Finance and Growth: Schumpeter Might Be Right. The Quarterly Journal of Economics, pages 717-737.

Kiyotaki, N. and Moore, J. (1997). Credit Cycles. The Journal of Political Economy, $105(2): 211-248$.

Krishnamurthy, A. and Muir, T. (2016). How Credit Cycles across a Financial Crisis. Mimeo.

Mendoza, E. G. (2010). Sudden Stops, Financial Crises, and Leverage. American Economic Review, 100(5):1941-1966.

Midrigan, V. and Xu, D. Y. (2014). Finance and Misallocation: Evidence from Plant-Level Data. American Economic Review, 104(2):422-458.

Muir, T. (2017). Financial Crises and Risk Premia. Quarterly Journal of Economics, forthcoming.

Olley, G. S. and Pakes, A. (1996). The Dynamics of Productivity in the Telecommunications Equipment Industry. Econometrica, 64(6):1263-1297.

Queraltó, A. (2016). A Model of Slow Recoveries from Financial Crises. Board of Governors Working Paper. 
Rajan, R. G. and Zingales, L. (1998). Financial Dependence and Growth. American Economic Review, 88(3):559-586.

Redmond, M. and Van Zandweghe, W. (2016). The Lasting Damage from the Financial Crisis to US Productivity. Federal Reserve Bank of Kansas City, Economic Review, 101(1).

Reinhart, C. M. and Rogoff, K. S. (2009). The Aftermath of Financial Crises. American Economic Review, 99(2):466-472.

Schmitz, T. (2017). Endogenous Growth, Firm Heterogeneity and the Long-run Consequences of Financial Crises. Mimeo.

Shourideh, A. and Zetlin-Jones, A. (2017). External Financing and the Role of Financial Frictions over the Business Cycle: Measurement and Theory. Journal of Monetary Economics, forthcoming. 


\section{A Appendix}

\section{A.1 Computation of the Equilibrium}

Given a set of structural parameters, I need to solve numerically for the optimal investment in tangible and in intangible capital of a firm as a function of its state variables. The method employed is value function iteration. The computational algorithm consists of the following steps:

1. Construct a grid of state values for $k, \frac{a}{k}, \frac{b}{k+a}, z, A$, and the three possible values for $M$. The grid is denser in regions of the state space where the continuation and the liquidation value are closer.

2. Assume a parametric form for the continuation function $\mathcal{C}$ in each aggregate state $M$. To save on parameters, I replicate the form of the analytical value function without frictions and idiosyncratic shocks. The parametric form is linear in $\{r, z r, k, a, b\}$, where $r \equiv p y-T-W l$ are revenues net of fixed and labor costs. Let us see why these are the relevant terms. If the firm continues production forever, the analytical solution is linear on debt $b$ and $r$, which is a function of the current state vector $(k, a, A, b, z, M)$ given the optimal choice for labor. If the firm liquidates production, the analytical solution is linear on the stocks of physical $k$ and intangible $a$ capital and debt $b$ (if $b<\bar{b}$ ). To capture the value of the idiosyncratic shock to depreciation $z$, which correlates with next period's $z$ and thus to accumulation of private intangible capital, I add the term $z r$ to the linear specification. The term is interacted with $r$ because $z$ is more valuable if the firm continues operating. Iterating on the continuation function rather than on the current-period value function allows me to solve analytically for the non-differentiable continuation-liquidation decision in the current period.

3. Use non-uniform discretization to compute expectations over realizations of $z^{\prime}$ given an aggregate state $M^{\prime}$. Again, the discretization is denser for regions where the liquidation option is closer (i.e. for high $z^{\prime}$ ). To compute expectations for $A^{\prime}$, I approximate $A^{\prime}=f(M)+A$, and iterate on the values of $f$ with the simulated data. ${ }^{38}$

4. Maximize numerically over investment in the two types of capital $i_{k}$ and $i_{a}$ for each grid point, taking into account:

\footnotetext{
${ }^{38}$ This is only an approximation because growth in $A^{\prime}$, which depends on the distribution of private intangible investment $i_{a}$ across firms, is affected by the distribution of state variables other than $M$. However, fluctuations in A are typically two orders of magnitude smaller than $A$, so approximation error does not substantially affect the investment policy functions.
} 
(a) labor optimality in equation (19),

(b) dividends optimality, i.e., $d=0$, and

(c) bond pricing by investors given by equation (21).

5. Iterate until the coefficients in the parametric guess for the continuation value function converge. The correlation between the grid values produced by the old and the new guess of the continuation value function must be higher than 99.99 percent.

6. Compute investment policy functions for $\frac{i_{k}}{k+a}$ and $\frac{i_{a}}{k+a}$ with a rich parametric form, linear on

$$
\left\{1, p y, r, \frac{r}{k}, \frac{r}{a}, r z, \frac{r b}{k+a}, \frac{1}{r}, k, k^{2}, \frac{a}{k+a},\left(\frac{a}{k+a}\right)^{2}, A, \frac{b}{k+a},\left(\frac{b}{k+a}\right)^{2}, \frac{1}{k+a-b}, z, \frac{z b}{k+a}, z k, \frac{z a}{k+a}\right\} .
$$

The parametrization of investment rates can be richer than the one for the continuation function because it is only used for simulation, not iteration.

7. Simulate an economy with as many heterogeneous firms as in the data for many periods, using the parametric investment policy functions. Compute the moments of interest both in the simulated and in the real data for the period 1992-2013, using the aggregate shock process for $M$ inferred from the E.U. data.

8. Iterate on the model's fundamental parameters until the GMM optimal distance measure between simulated and data moments is minimized. See Section 4 for a more detailed description of the two last steps.

\section{A.2 Benchmark Model: Exogenous Intangible Investment}

I compare my endogenous intangible investment model against a standard model with exogenous idiosyncratic productivity shocks. The benchmark model is equivalent to Midrigan and Xu (2014) (which builds on Kiyotaki and Moore (1997)), with the addition of endogenous default. It has no endogenous intangible investment and no spillovers.

In particular, in the benchmark model, intangible investment $i_{a}$ is fixed at the same level for all firms, costs no resources and has no adjustment costs. The level of $i_{a}$ is chosen to replicate the level of private intangible capital in the full model. I assume entrants start with the same level of intangible capital as in the full model. I also suppress spillovers, fixing the (post-normalization) public stock of intangibles to $A=1$. The idiosyncratic intangible depreciation shock $z$ is maintained: it enters as an exogenous productivity shock. These assumptions eliminate the endogenous response of intangible investment to financial shocks and the forces that generate persistence: spillovers and adjustment costs. 
Finally, I assume that a fraction of a firm's profits is paid out in the form of dividends every period, such that the post-dividend frictionless profit level is the same as in the full model. Otherwise, the absence of intangible investment expenditures would make firms more profitable and less leveraged, reducing the impact of financial shocks. Hence, this extra assumption is conservative in that it reduces the gap with the full model.

For comparability, I calibrate the initial level of equity $-b_{0}$ to match the average size of entrants in the full model and reestimate the entry cost $\gamma$ to allow for realistic changes in net entry over time. The rest of parameters are unchanged.

\section{A.3 Firm-Level Data Variables}

Table 5 provides summary statistics for the variables used in structural estimation and the rules used for winsorizing outliers, as well as the correspondence with the variable names in the original datasets (ESEE and DIRCE). With respect to the legal form of the firm, I exclude from the sample self-employed owners, cooperative firms and the category "Other", which together constitute less than 6 percent of the sample. These leaves limited liability companies (Sociedad Limitada in Spanish) and stock corporations (Sociedad Anónima), which correspond to ESEE variable FORJUR $=\{2,3\}$.

\section{A.4 Additional Non-Targeted Moments}

Firm life cycle Figure 12 replicates Figure 3 in the data. It plots tangible and intangible investment rates and leverage rates as a function of the age of the firm. I average every two years in the data to minimize the error due to the low number of observations for some firm ages. The data shows the same qualitative patterns as the model, but the intangible investment rate is much lower for very young firms, probably due to lack of reporting of this variable.

Leverage distribution Figure 13 plots the distribution of leverage across firms, weighted by the value added share of each bin, in the data and in the model. More than 35 percent of the firms in the data, weighting by their value-added contribution, have a leverage ratio below 5 percent, and the contribution of firms with leverage ratios above 50 percent is very modest. Hence, the room for restrictions in external financing to affect aggregate investment is limited. My model shows how financial constraints can generate persistent effects even if only a small fraction of firms are affected by them. The estimation of the model only targets average leverage, so the fit in the distribution is not perfect. The model produces a bimodal leverage distribution, with some apparent bunching around the endogenous borrowing constrain of 
Figure 12: Firm Life Cycle, Data

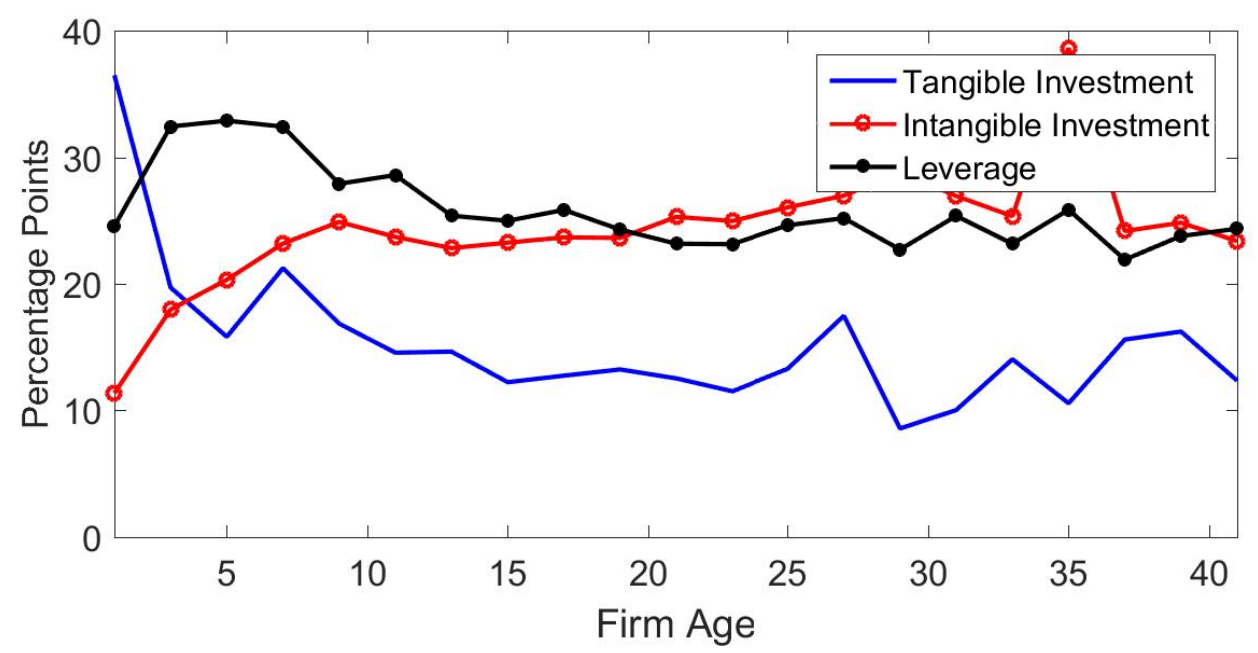

Notes: In this Figure, tangible and intangible investment are rates to tangible and intangible capital respectively. Leverage is debt over total assets.

each firm. Yet, the presence of firm heterogeneity and endogenous default in equilibrium allow the model to produce a flatter distribution of leverage values than the one predicted by models without default in equilibrium.

Cross-industry evidence Figure 14 shows that asset tangibility also influenced the behavior of different industries in the Great Recession. The figure plots, for each industry, the change in the average total investment rate $\frac{i_{k}+i_{a}}{k+a}$ from the period 1991-2008 to 2008-2013, as a function of the average tangibility for 1991-2008. ${ }^{39}$ Industries are classified into 20 sectors of activity within the manufacturing sector. Firms in industries with lower average asset tangibility were the ones that reduced their investment rates more after the Great Recession.

\section{A.5 Computation of Standard Errors}

This Section describes the computation of standard errors for the moments and for the parameters.

I compute the variance-covariance matrix for firm-level moments in the data and in the model by block bootstrap with 500 samples. Bootstrap samples are generated with random draws at the firm-level. To compute standard errors for aggregate entry and exit rates, I assume that these two variables follow a joint VAR(1) process. Since the firm-level and aggregate moments come from two separate datasets, for tractability I assume that

\footnotetext{
${ }^{39}$ These are averages across firms in an industry, as opposed to industry aggregates, to avoid that a large firm in an industry drives the results. The positive correlation is also present for industry aggregates.
} 
Figure 13: Leverage Distribution

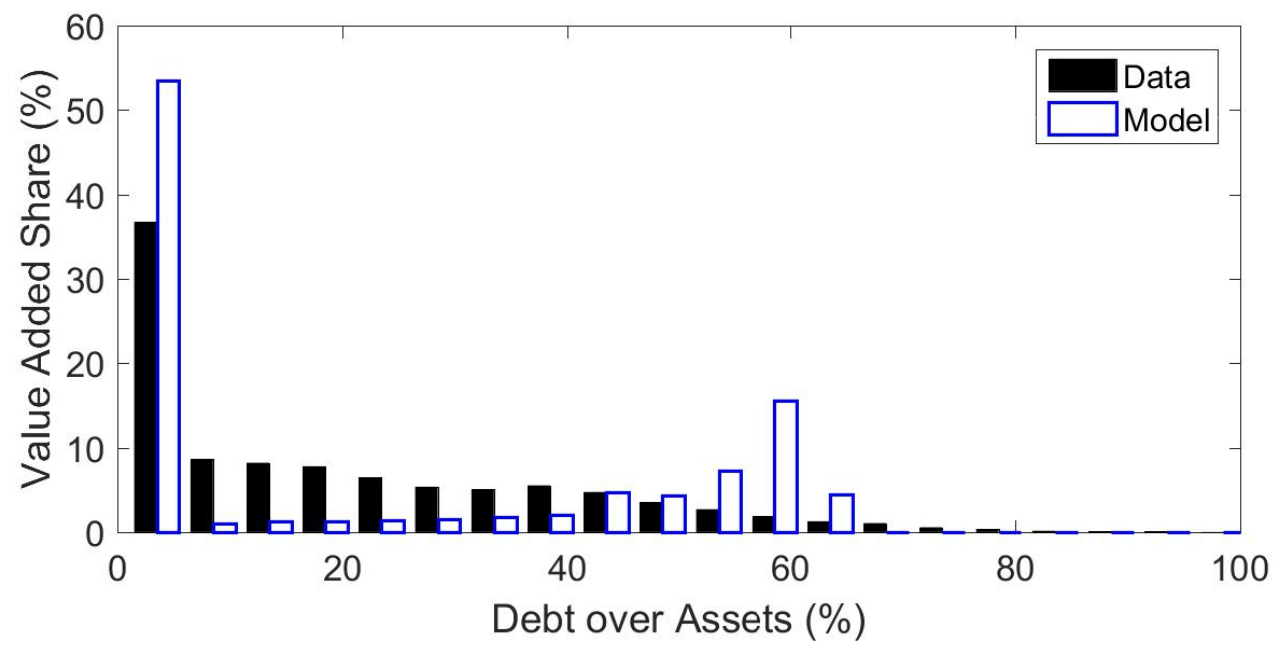

Sample: Spanish manufacturing firms, 1992-2013 average. Source: ESEE.

their cross-covariances are zero, although the presence of aggregate shocks could potentially generate a correlation.

The variance-covariance matrix for the parameters is given by

$$
\left(H^{\prime} \Sigma^{-1} H\right)^{-1}+\left(H^{\prime} \widetilde{\Sigma}^{-1} H\right)^{-1}
$$

where $H$ is the Jacobian matrix (computed as the average of the 1 and -1 percent numerical gradient), $\Sigma$ is the estimated variance-covariance matrix of the moments in the data, and $\widetilde{\Sigma}$ is the equivalent of $\Sigma$ for the model-simulated data. The second term in the summation accounts for the error due to the simulation of one finite sample of observations from the model (see Gourieroux and Monfort (1997)). For parameters whose estimated standard error is smaller than the minimum grid step in the maximization algorithm, I report the grid step as an upper bound for the standard error. This is the case for $\psi_{k}, \eta_{k}$ and $\theta$.

The weighting matrix used to measure the distance between data and model-simulated moments is $\Sigma^{-1}$. 
Figure 14: Post-2008 Change in Investment Rate by Industry Tangibility

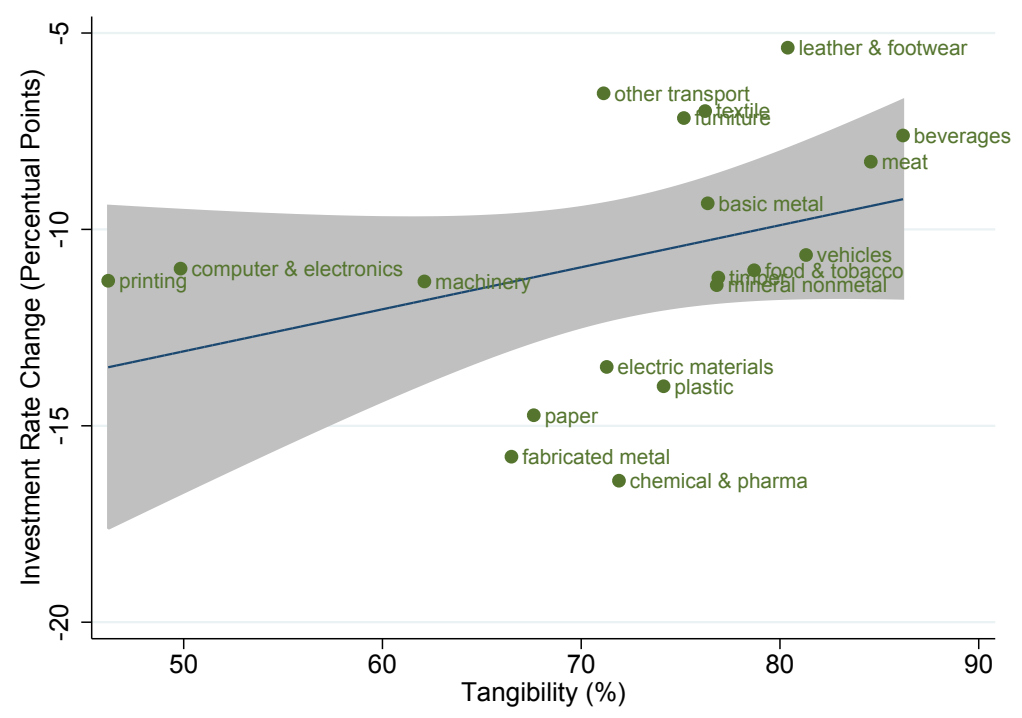

Notes: Investment rate change between 1991-2008 and 2008-2013. Average tangibility computed for 1991-2013. Sample: Spanish manufacturing firms. Source: ESEE. 
Table 5: Data Variables

(a) Summary Statistics

\begin{tabular}{lcrrrr}
\hline concept (unit) & label & mean & 10th pctile. & 90th pctile. & winsorizing \\
\hline value added (EUR $\left.{ }^{*}\right)$ & $p y$ & $2,023,511$ & 200,465 & $2,130,631$ & - \\
phys. capital (EUR $\left.{ }^{*}\right)$ & $k$ & $1,720,838$ & 26,948 & $2,100,430$ & $>$ EUR100 \\
tangibility (\%) & $\frac{k}{k+a}$ & 73.0 & 28.9 & 100.0 & INM > EUR100 \\
leverage (\%) & $\left(\frac{b}{k+a}\right)^{+}$ & 26.8 & 0 & 63.4 & $<100 \%$ \\
tang. invest. rate (\%) & $\frac{i_{k}}{k+a}$ & 11.1 & 0 & 34.7 & $< \pm 200 \%$ \\
intang. invest. rate (\%) & $\frac{i_{a}}{k+a}$ & 6.9 & 0 & 18.8 & $< \pm 200 \%$ \\
age (years) & - & 22.6 & 6 & 42 & - \\
labor share (\%) & $\frac{W l}{p y}$ & 62.3 & - & - & - \\
entry rate (\%) & - & 5.2 & - & - & - \\
exit rate (\%) & - & 2.7 & - & - & - \\
entrants rel. empl. (\%) & - & 57.1 & - & - & - \\
firm weights & - & 0.84 & 0.04 & 2.95 & \\
\hline
\end{tabular}

(b) Variable Definitions

\begin{tabular}{lcl}
\hline concept (unit) & label & name/formula in survey \\
\hline value added (EUR $\left.{ }^{*}\right)$ & $p y$ & VA \\
phys. capital (EUR $\left.{ }^{*}\right)$ & $k$ & IN-INM \\
tangibility (\%) & $\frac{k}{k+a}$ & $($ IN-INM)/IN \\
leverage (\%) & $\left(\frac{b}{k+a}\right)^{+}$ & FACC/PASIVO \\
tang. invest. rate (\%) & $\frac{i_{k}}{k+a}$ & $(\mathrm{CIM-VIM)/IN}$ \\
intang. invest. rate (\%) & $\frac{i_{a}}{k+a}$ & (GEFT+GTID+GPV*VENTAS/100+IMPTEC)/IN \\
age (years) & - & year-AEMP \\
labor share (\%) & $\frac{W l}{p y}$ & CP/VA \\
entry rate (\%) & - & DIRCE Tables 287-292, Altas/Total \\
exit rate (\%) & - & DIRCE Tables 287-292, Bajas/Total \\
entrants rel. empl. (\%) & - & PERTOT \\
firm weights & - & DIRCE Tables 296, 297 \\
\hline
\end{tabular}

Notes: $\left(^{*}\right)$ monetary units are 2008 Euros. Entrants $($ age $=<5)$ employment is relative to older firms (age $\left.>5\right)$. 